\title{
Immunological Approaches to the Treatment of New Coronavirus Infection (Review)
}

DOI: 10.17691/stm2021.13.3.09

Received March 20, 2021

N.A. Lyubavina, MD, PhD, Associate Professor, Department of Propedeutics of Internal Diseases:

S.G. Saltsev, MD, PhD, Associate Professor, Department of Propedeutics of Internal Diseases;

N.V. Menkov, MD, PhD, Associate Professor, Department of Propedeutics of Internal Diseases;

L.V. Tyurikova, MD, PhD, Associate Professor, Department of Propedeutics of Internal Diseases;

S.S. Plastinina, MD, PhD, Associate Professor, Department of Propedeutics of Internal Diseases;

M.L. Shonia, MD, PhD, Associate Professor, Department of Propedeutics of Internal Diseases;

A.A. Tulichev, MD, PhD, Assistant, Department of Propedeutics of Internal Diseases;

M.Yu. Milyutina, Assistant, Department of Propedeutics of Internal Diseases;

E.V. Makarova, MD, DSc, Associate Professor, Head of the Department of Propedeutics of Internal Diseases

Privolzhsky Research Medical University, 10/1 Minin and Pozharsky Square, Nizhny Novgorod, 603005, Russia

The pandemic of the new coronavirus infection (COVID-19) caused by the SARS-CoV-2 virus has spread all over the world. The large amount of information that appears every day requires comprehension and systematization. The immunological aspects of the virus-host interaction are the core issues in the effective treatment and prevention of COVID-19' development.

The review analyzes the known pathways of the viral invasion and evasion, the mechanisms of the cytokine storm, endothelial damage, and hypercoagulability associated with SARS-CoV-2 infection. Clinical data from previous SARS and MERS epidemics is discussed here. We also address the therapeutic approaches based on the basic knowledge of immune response and the blood cells' immune functions, as well as the ways to reduce their hyperactivation. The use of interferon therapy, anti-inflammatory therapy, anti-cytokine therapy, neutralizing antibodies, convalescent plasma, and mesenchymal stem cells, as well as prophylactic vaccines, is discussed.

Key words: COVID-19; SARS-CoV-2; coronavirus infection; pneumonia; lung damage; cytokine storm; immune response; prophylactic vaccines.

How to cite: Lyubavina N.A., Saltsev S.G., Menkov N.V., Tyurikova L.V., Plastinina S.S., Shonia M.L., Tulichev A.A., Milyutina M.Yu., Makarova E.V. Immunological approaches to the treatment of new coronavirus infection (review). Sovremennye tehnologii v medicine 2021; 13(3): 81, https://doi.org/10.17691/stm2021.13.3.09

This is an open access article under the CC BY 4.0 license (https://creativecommons.org/licenses/by/4.0/).

\section{Introduction}

The pandemic of the new coronavirus infection (COVID-19) caused by the beta coronavirus SARSCoV-2 has caused high morbidity and mortality worldwide [1]. The severity of COVID-19 ranges from asymptomatic to fatal pneumonitis [2]. SARS-CoV-2 is closely related to SARS (retrospectively named SARS-CoV-1) and the Middle East respiratory syndrome MERS-CoV, which caused zoonotic epidemics and localized outbreaks in 2003 and 2012, respectively [3-5]. Consequently, it is important to learn the lessons from the two previous coronavirus epidemics. Although SARS-CoV-2 is not nearly as deadly as SARS-CoV-1 or MERS-CoV [6], the rapid spread of the current infection has led to disastrous consequences for health systems around the world.

Numerous studies have shown that the penetration of the SARS-CoV-2 coronavirus into the cell is a result of interaction between the receptor-binding domain of the viral spike (S) protein and the angiotensinconverting enzyme receptor 2 (ACE2). The ACE2 is present on non-immune cells (respiratory and intestinal epithelial cells, endothelial cells, renal tubule cells, and brain neurons), as well as on immune cells (alveolar monocytes/macrophages) [7-9]. Binding of the viral $S$ protein to the ACE2 receptor leads to the suppression of the latter followed by lung damage [10]. A better understanding of these immunological processes will allow to develop therapeutic and preventive measures against COVID-19 [11].

\section{Mechanisms of the immune response to SARS-CoV-2}

\section{Innate immune response}

The innate immune response serves as the first line of antiviral defense. There is a so-called mechanism

Corresponding author: Natalia A. Lyubavina, e-mail: n.lubavina@yandex.ru 
of evasion, which allows them to evade the immune response, in coronaviruses. When the pattern-recognition receptors of immune cells interact with the viral RNA, the secretion of cytokines is triggered through signaling cascades. Among the cytokines, the most important for antiviral protection are type I and III interferons (IFN-I and IFN-III); in addition, other cytokines - pro-inflammatory tumor necrosis factor alpha (TNF- $\alpha$ ), interleukins IL-1, $\mathrm{IL}-6$, and IL-18 - are also released. Together, they induce an antiviral mechanism in target cells and potentiate the adaptive immune response. If it is initiated at an early stage and is powerful enough, IFN-I will be able to effectively limit the development of coronavirus infection and lead to pathogen elimination and patient recovery $[12,13]$. Studies [14-17] have shown that SARS-CoV-2 is more sensitive to IFN-I and IFN-III than SARS-CoV-1 in laboratory conditions.

Cytokines represent a major barrier to viral infection; to avoid this barrier, coronaviruses have evolved mechanisms able to inhibit the induction and signaling of IFN-I. The SARS-CoV-2 virus suppresses the induction of intracellular interferon, while the virus is sensitive to exogenous IFN-I. Numerous studies [14, 18-22] have shown the ability of coronaviruses to inhibit interferon production in vitro and in vivo. In real clinical practice, patients with severe COVID-19 show a significant decrease in the effect of IFN-I compared to patients with mild to moderate cases of COVID-19 [23].

The existence of the pathways, especially that of IFN-I, that allow pathogenic coronaviruses to evade the immune response suggests a role for dysregulation of the IFN-I response in the pathogenesis of COVID-19. Pathogenic coronaviruses not only block interferon signaling but also participate in other inflammatory pathways. For example, the non-structural proteins NSP9 and NSP10 of SARS-CoV-2 can induce the production of IL-6 and IL-8 [24].

Innate lymphoid cells are cytotoxic natural killer (NK) cells located in the lungs and able to prevent pathogens from entering the tissue. These cells do not express the ACE2 receptor and are, therefore, unlikely to be directly infected with SARS-CoV-2 [25]. Information of the number of NK cells in patients with COVID-19 is not consistent; yet these cells are assumed to play a role in the cytokine release syndrome [26, 27]. Studies $[28,29]$ indicate that in severe SARS-CoV-2 infections, the number of NK cells is reduced. After successful recovery from COVID-19, the NK cell number is restored to normal levels. Some reports [27, 30] indicate either a disturbance in the NK cell maturation or migration of mature circulating NK cells into the lungs or other peripheral tissues in patients infected with SARS-CoV-2.

An ex vivo study of NK cells from the peripheral blood of patients with COVID-19 revealed a decrease in the expression of CD107a, caspase Ksp37, granzyme B, and granulysin; these changes could result in reduced cytotoxicity and insufficient production of IFN- $\gamma$ and TNF- $\alpha[31,32]$.
Patients with COVID-19 have increased plasma concentrations of IL-6 [32], which significantly correlated with a reduced number of NK cells $[27,33]$. It has been shown that in vitro stimulation of IL-6 and its soluble receptor (IL6R) inhibits the cytolytic functions (production of perforin and granzyme B) of NK cells; this inhibition can be reversed by tocilizumab that blocks IL6R [34]. In addition, TNF- $\alpha$ secreted by monocytes regulates the differentiation of NK cells [35] and is able to bind to the specific receptors on NK cells [36]. The level of TNF- $\alpha$ was found to be increased in the blood plasma of patients with COVID-19 [32]. Thus, dysfunction of monocytes can negatively affect the antiviral function of NK cells in people infected with SARS-CoV-2.

Monocytes/macrophages and dendritic cells play a crucial role in antiviral responses, linking innate and adaptive immunity. Peripheral activation and accumulation of activated pro-inflammatory monocytes/ macrophages in the lungs are recognized as one of the COVID-19 symptoms [37]. The SARS-CoV-2 virus activates monocytes/macrophages and triggers the production of pro-inflammatory mediators - IL-6, GMCSF, IL-1 $\beta$, TNF, CXCL-8, CCL-3 - and accelerated cell death. This can subsequently initiate a cytokine storm, which is also known as cytokine release syndrome. Some of these cytokines (for example, IL-6) are mainly secreted by macrophages, leading to macrophage activation syndrome [38-40]. Activated and subsequently dying macrophages contribute to high levels of ferritin in the blood plasma and dysregulation of iron metabolism. Abnormally high ferritin is one of the biomarkers for patients with severe COVID-19 [41, 42].

Thus, a therapy aimed at reducing the activity of macrophages may become promising means of suppressing the inflammatory storm during coronavirus infection.

Flow cytometric analysis of peripheral blood mononuclear cells from patients with advanced COVID-19 showed a significant rise in activated CD4+ $\mathrm{T}$ cells and CD14+HLA-DR ${ }^{\text {lo }}$ inflammatory monocytes known to produce granulocyte-macrophage colonystimulating factor (GM-CSF) [43, 44]. Significantly increased systemic levels of the proinflammatory cytokine IL-6 were reported in several cohorts of COVID-19 patients; the levels of IL- 6 correlated with disease severity [45]. Elevated levels of IL-6 might also be associated with high levels of IL-2, IL-7, IFN- $\gamma$, and GM-CSF found in secondary viral hemophagocytic lymphohistiocytosis (unregulated macrophage activation and unregulated phagocytosis). It is known that in response to viral infections, mononuclear cells increase their production of interleukins, IFN-I and IFN-III. This leads to the activation of inflammation, the induction of pathogenic reactions of Th1 and Th17 cells, the recruitment of effector immune cells, and the cytokine storm [46, 47].

Along with that, studies on SARS-CoV-2 and other coronaviruses showed that IL-6, IL-1 $\beta$, and IFN-I/IFN-III from infected pulmonary epithelium are capable of 
inducing hyperinflammation cascades in resident (alternative) macrophages while simultaneously recruiting inflammatory monocytes, granulocytes, and lymphocytes from the bloodstream. This systemic inflammatory response can cause neutrophilic NETosis and microthrombosis, exacerbating the severity of COVID-19 [48].

T-lymphocytes play a fundamental role in the antiviral response mediated by $\mathrm{CD} 4+\mathrm{T}$ cell-secreted cytokines, CD8+ T cell cytotoxicity, and B cell activation, ultimately leading to the production of antibodies. New coronaviruses can bypass these protective mechanisms by inducing apoptosis of $\mathrm{T}$ cells, as well as depleting the pool of lymphocytes that enter the lungs and trigger hyperinflammation during the cytokine storm [49-52]. Dysregulation of $T$ cell responses can lead to immunopathology.

It is important to clarify the role of T cells in the early immune response to the virus to understand the role of $\mathrm{T}$ cell responses. Previous studies on SARS-CoV-1 [53], as well as a number of recent studies on SARSCoV-2 [27, 29, 54-56], indicate the development of lymphopenia with a sharply reduced number of both CD4 and CD8 T cells in moderate and severe clinical forms. The degree of lymphopenia, mainly CD8 T cells, in ICU patients correlated with the severity and mortality associated with COVID-19 [27, 39, 54, 57]. However, patients with mild COVID-19 usually have a normal or slightly increased number of $T$ cells $[58,59]$. The reason for the loss of peripheral $T$ cells in moderate to severe COVID-19 needs further research since direct viral damage to $\mathrm{T}$ cells by SARS-CoV-2 was not found, in contrast to MERS-CoV [60].

Various mechanisms are likely to contribute $T$ cells decrease in the blood, including the effects of inflammatory cytokines. Lymphopenia correlates with serum levels of IL-6, IL-10, and TNF- $\alpha$, while recovery in the number of $T$ cells along with lower levels of proinflammatory cytokines is noted in convalescent patients [29, 57, 61]. The cytokines IFN-I and TNF- $\alpha$ promote the retention of $\mathrm{T}$ cells in the lymphoid organs and their attachment to the endothelium [62, 63]. Autopsy findings indicated massive lymphocyte death in the spleen and enlarged intrathoracic lymph nodes of patients who died from COVID-19; a possible role of IL-6 and the Fas-FasL interactions was proposed. In support of this hypothesis, the IL-6 receptor antagonist tocilizumab was found to increase the number of circulating lymphocytes [43]. Recruiting $T$ cells to the sites of infection can also reduce their presence in the peripheral blood. An increased number of CD8 $T$ cells was found in the bronchoalveolar lavage fluid of patients with COVID-19 [37]. Similarly, autopsy of a patient with SARS-CoV-2 revealed extensive lymphocyte infiltration in the lungs [64], although another study found only neutrophil infiltration [65]. Therefore, further studies are needed to determine the cause and consequence of lymphopenia in patients with COVID-19.
In the study [39], it was suggested that dysregulation of $\mathrm{T}$ cell responses could provoke a more severe course of COVID-19. A significant increase in GM-CSF+ CD4 $T$ cells with extremely high ex vivo IL-6 and IFN-y production was reported in critically ill COVID-19 patients. In addition, a decrease in the level of regulatory $T$ cells was noted in severe cases of the disease [28, 54].

Regulatory $\mathrm{T}$ cells help to resolve the inflammation in acute respiratory distress syndrome (ARDS) in mice [66]. A decrease in $y \delta ~ T$ cells, a subset of $T$ cells with protective antiviral function, was found in critically ill patients with COVID-19 [67]. Therefore, T cell deficit can lead to lung immunopathology in COVID-19.

Currently, little is known about specific functional changes in T cells associated with COVID-19. Most publications [36, 37, 58, 68, 69] report an increased presence of activated $\mathrm{T}$ cells characterized by the expression of HLA-DR, CD38, CD69, and CD25. As a rule, regardless of COVID-19 severity, the activation of CD8 T cells is more pronounced than that of CD4 $T$ cells $[28,58]$. Zheng et al. [29] noted that in critical forms of COVID-19, the number of polyfunctional T cells (producing more than one cytokine) was reduced in parallel with the production of IFN- $\gamma$, TNF- $\alpha$, and granzyme B. Another study [69] demonstrated an increase in the granzyme B and perforin levels in CD8 $T$ cells of critically ill patients.

In severe COVID-19 T cells seem to be overactivated and may become exhausted due to continuous expression of inhibitory markers, as well as decreased polyfunctionality and cytotoxicity. Conversely, there is an increase in follicular helper CD4 T cells in convalescent patients, as well as a decrease in the level of inhibitory markers, along with an increase in the level of effector molecules such as granzyme A, granzyme B, and perforin $[29,58]$.

In addition, memory $\mathrm{T}$ cells contribute to protective immunity during reinfection. Only a few studies addressed the specific $\mathrm{T}$ cell immunity in SARS-CoV-2 infection until now. A correlation was found between the neutralizing antibody titers and the number of virusspecific T cells [68] in mild COVID-19 convalescents. In another study, virus-specific CD4 and CD8 memory $T$ cells were found in the peripheral blood of patients with moderate to severe ARDS [70].

Together, these proinflammatory processes are likely to lead to the cytokine storm developing in COVID-19 patients, which rationalizes the use of targeted immunosuppressive therapies. A clear understanding of the delicate balance between antiviral and inflammatory innate immune programs is essential for finding effective biomarkers and treatments for COVID-19.

\section{Humoral immune response}

The humoral immune response is critical for the clearance of cytopathic viruses and plays a major role in the memory mechanism that prevents reinfection. SARS- 
CoV-2 induces a sustained B cell response, as evidenced by the rapid and almost universal detection of virusspecific $\lg M$, IgG, and $\lg A$, as well as neutralizing $\lg G$ antibodies, within days of infection. Kinetics of antibody response to SARS-CoV-2 is well described [71, 72].

Currently, studies on COVID-19 mainly focus on the IgG response to SARS-CoV-2 infection, because this line of research is highly important for the development of vaccines and therapeutic agents. IgG antibodies to various SARS-CoV-2 proteins can be determined in laboratory setting.

$\mathrm{S}$ and $\mathrm{N}$ protein-specific antibodies were assayed in serological studies [68, 73]. Antibodies against the $S$ protein prevent the virus from binding to the host cells and are, therefore, able to effectively neutralize the virus. The presence of circulating IgG specific for the viral $\mathrm{N}$ protein is considered as a marker of previous infection. It was found out $[74,75]$ that the levels of antiSARS-CoV-2-IgG against the viral nucleoprotein or the receptor-binding domain of the $S$ protein correlated with the virus-neutralizing activity.

In previous epidemic outbreaks of coronavirus infections, serological responses to beta-coronaviruses varied. In SARS-CoV, specific IgG antibodies were found in all patients [76]; in milder forms of MERS-CoV, some patients did not show IgG at a sufficient level [77]. Currently, a number of studies of humoral immune responses [68, 71, 74, 78-80] report the appearance of IgG antibodies against SARS-CoV-2 in the blood serum of most patients. Some patients, mostly with mild forms of the disease, remained seronegative [81-83], which was likely associated with a short follow-up period (less than 25-50 days). A 90-day follow-up showed that IgG was not produced in $9 \%$ (3 of 32 ) of patients with mild symptoms of COVID-19, although all patients, including seronegative, showed neutralizing antibodies, indicating developed humoral immunity [84].

Therefore, seroconversion is likely to occur detected in all patients, but the sensitivity and specificity of $\lg G$ detection might be different.

Among those who had recovered after the SARS-CoV epidemic of 2003, the level of neutralizing antibodies remained significant for 3 years; in some reports, these antibodies persist to the present. Moreover, these persistent antibodies may have a neutralizing effect against the current coronavirus infection [85]. The duration of protective immunity against SARS-CoV-2 is currently unknown.

Information about the dynamics of the antibody response and serological status is ambiguous. Thus, Long et al. [78, 86] report that in $97 \%$ of 37 patients with mild COVID-19, the antibody titers decrease in 2-3 months after infection. According to Wajnberg et al. [87], the level of specific IgG remains stable for 82 days after the onset of symptoms. Marklund et al. [84] noted that the level of antibodies increased over time in some patients with either mild or severe forms of the disease. Xiao et al. [88] observed elevated levels of IgG in 34 patients with COVID-19 within 5 weeks of the onset of the disease; the values remained stable for 7 weeks. A number of reports $[84,89,90]$ indicate that seroconversion occurs earlier among severely ill patients and specific antibodies are produced at a higher level. In addition, study [91] noted that gender did not significantly affect the serum level of anti-SARS-CoV-2 lgG in severe COVID-19.

The small number of published studies and the inconsistency of accumulated data do not allow us to draw final conclusions about the features and dynamics of humoral immunity in different forms of COVID-19. Further studies are required for the development of vaccines and pharmacotherapy, personalization and differentiation of approaches to immunization against this infection.

\section{Immunology-based approaches to therapy and specific prevention of COVID-19}

\section{Interferon therapy}

SARS-CoV-2 effectively inhibits the expression of IFN-I. Given its strong immunomodulatory nature, the administration of IFN-I to COVID-19 patients in the early stages of the disease may prevent the development of immunopathologies in the later stages. Numerous clinical trials on the use of interferon therapy have been launched. A study on efficacy of IFN- $\alpha-1 \beta$ nasal drops combined with the immunomodulator thymosin a1 for the prevention of COVID-19 in high-risk medical staff is ongoing in China (NCT04320238, n=2944). A randomized clinical trial conducted in Iran [92] showed that the administration of IFN- $\beta-1 \alpha$ to patients with severe COVID-19 reduced their hospital stay and 28-day mortality, especially with early treatment. The use of IFN$\alpha 2-\beta$ in combination with Arbidol significantly reduced the virus persistence in the upper respiratory tract and shortened the presence of the inflammatory markers IL-6 and CRP in adults hospitalized with COVID-19 [93] at the same time. However, these therapies increase the risk of over-activation of proinflammatory signals, which can enhance immunopathological manifestations [94].

Type III interferons can become an alternative to IFN-I because they also possess antiviral functions but are less toxic in terms of mediating immunopathology [95]. IFN-III-IFN- $\lambda$ induces the production of IFN-y by NK cells indirectly through IL-12, which partially suppresses and slows the immune response [96, 97]. A placebocontrolled study of pegylated IFN- $\lambda$ is currently underway in patients with mild COVID-19 (NCT04331899, $n=120)$. The main advantage of IFN $-\lambda$ is that it can prevent the damaging effect of neutrophils on the lungs. On the other hand, it reduces the rate of tissue repair; in the context of COVID-19, which has a long time-course, this effect of IFN- $\lambda$ may increase a risk of secondary infections [98]. Administration of interferons can cause an imbalance in the immune response and severe immunopathology 
in COVID-19. Therefore, careful monitoring of safety and efficacy of interferon therapy should be a priority in the development of protocols and clinical trials [99].

\section{The use of neutralizing antibodies and convalescent plasma for COVID-19 therapy}

Neutralizing antibodies. The effectiveness of using neutralizing antibodies against SARS-CoV-1 and MERSCoV has been documented [100, 101,102]. In the case of SARS-CoV-2, research efforts are primarily focused on identifying antibodies produced in diseased patients or under conditions of animal vaccination.

To obtain antibodies that neutralize the SARS-CoV-2 virus from the blood of recovered patients, Chinese scientists isolated memory $B$ cells specific to the viral receptor-binding domain (RBD). Then these cells were cloned to express recombinant forms of the respective antibodies. The resulting four antibodies showed a high neutralizing potential in vitro. All of them inhibited the binding between ACE2 and RBD; however, blocking this interaction is not always a necessary condition for the effect of antibodies against SARS-CoV-2 [103].

Research is underway to obtain animal-raised antibodies that can be directly administered to SARSCoV-2 infected patients. Regeneron Pharmaceuticals synthesized a combination cocktail of two antibodies REGN-COV2. The preparation is good at reducing the viral load when the immune response has not yet been manifested or the initial viral load is high [104]. AstraZeneca and Oxford University have developed a preparation of 2 monoclonal antibodies to the $S$ protein of SARS-CoV-2 for the prevention of COVID-19 in adults. Therapy with anti-SARS-CoV-2 monoclonal antibodies seems promising since the medication can be used to block ongoing infection and as a prophylactic agent.

Convalescent plasma. Historically, passive immunotherapy used convalescent whole blood or convalescent plasma, human immunoglobulin, polyclonal or monoclonal antibodies. However, at present, the preference is given to plasma collected by apheresis [105]. The safety and efficacy of convalescent plasma in severe respiratory viral infections and severe COVID-19 are not fully studied [106, 107].

Studies conducted in a limited number of patients showed the potential efficacy of convalescent plasma transfusion as an adjunct treatment for severe COVID-19. The administration of 2 doses to 5 patients [108], 1 dose to 10 patients [109], and from 1 to 8 doses to 4 patients, including a pregnant woman [110], improved their clinical condition. A meta-analysis of 1 randomized controlled trial, 3 controlled and 10 uncontrolled clinical trials (5201 participants in total) on safety of convalescent plasma, revealed serious adverse events in the first $4 \mathrm{~h}$ after plasma transfusion. Other side effects were predominantly allergic or respiratory in nature, including anaphylaxis, shortness of breath, and acute lung injury. None of the studies reported adverse events in the control group [107].

The timing of convalescent plasma therapy is of great importance. In patients with SARS-CoV-1, the best results were observed with the administration of plasma before the $14^{\text {th }}$ day of illness [111], like it was found with influenza [112]. As shown, such therapy was more effective in PCR-positive, but seronegative patients, however, the amount of plasma and the frequency of transfusions require further study. The use of convalescent plasma from patients who have recovered from COVID-19 appears to be promising for the prevention of COVID-19 or when administered within 14 days after the onset of symptoms. Protection can last from several weeks to several months [109, 113, 114].

The results of a retrospective analysis of the use of convalescent plasma in 3082 adult patients treated in US hospitals for COVID-19 were published [115] in January 2021. A decrease in mortality was noted following the use of plasma with high titers (but not low titers) of specific antibodies in patients without mechanical ventilation. Initiation of anti-COVID plasma therapy up to 3 days after confirming the diagnosis of COVID-19 was associated with a lower mortality rate, in comparison to the later initiation of treatment.

Several non-randomized trials [108-110, 116, 117] showed the safety of convalescent plasma therapy and its beneficial effect in patients with severe COVID-19. Convalescent plasma has also been proposed for prophylactic use in people at risk (with comorbid pathology) or in medical staff who have been in contact with patients with COVID-19. The FDA has approved the use of convalescent plasma for the treatment of critically ill patients [118].

Other advantages of convalescent plasma include its availability and the seemingly low incidence of serious side effects. However, this cannot justify using a treatment with unproven efficacy. It is necessary to conduct randomized clinical trials to determine the optimal timing and indications for this therapy [119].

\section{Anti-inflammation therapy. Glucocorticoids}

The host's immune response plays a key role in the pathogenesis of severe COVID-19. Over time, it became obvious that lung damage in COVID-19 develops against the background of both overstimulation and suppression of the immune response [120]. Typically, there is a clinical picture of massive vascular inflammation, disseminated intravascular coagulation, shock, and ARDS [32, 120, 121]. Patients with severe COVID-19 face a double challenge. On the one hand, their fight against a viral infection necessitates the virus elimination from the body. On the other hand, the patients suffer from hyperinflammatory reactions, pulmonary thrombosis, increased vascular permeability, and ARDS [122]; those disorders necessitate the use of glucocorticoids (GCs) [123]. 


\section{REVIEWS}

The anti-inflammatory effect of GCs can help overcome both hyperstimulation of the immune system and inflammation, as well as ARDS [123-126]. These medications are easily available and the treatment is cost-effective. However, the use of GCs was associated with the development of side effects in previous studies [127-132] with SARS-CoV-1 and MERS-CoV. Among them there was a slowdown in viral clearance, an increase in opportunistic infections, hyperglycemia, and suppression of the hypothalamic-pituitary-adrenal axis; those complications may limit the use of GCs in coronavirus infections. Therefore, during the SARSCoV-2 pandemic, a large number of observational and randomized controlled trials were launched to study the efficacy of GCs against COVID-19.

Thus, preliminary results of the RECOVERY randomized trial [133] on dexamethasone therapy in hospitalized adults with confirmed COVID-19 were published in June 2020. For the first time dexamethasone was found superior to the standard treatment in reducing 28-day mortality in patients requiring oxygen therapy or mechanical ventilation.

In a prospective meta-analysis of seven randomized clinical trials, the administration of GCs was shown to be associated with a lower 28-day mortality from any cause [134]. WHO recommended against using GC medications in the early days of the pandemic. Currently, WHO proposes using systemic GCs for severe and critical forms of COVID-19, as well as in refractory shock and, if necessary, in patients with ARDS on mechanical ventilation $[125,135,136]$.

In December 2020, Van Paassen et al. [137] published a systematic review and meta-analysis of 44 studies evaluating the efficacy of GC therapy in COVID-19, involving 20,197 patients aged 34 to 75 years. It was found that systemic GCs significantly had reduced short-term mortality (OR $0.72,95 \% \mathrm{Cl} 0.57-0.87$ ) and the need for mechanical ventilation in patients with acute respiratory failure (OR $0.71,95 \% \mathrm{Cl} 0.54-0.97$ ). However, it is too early to draw conclusions about the efficacy and safety of GCs in COVID-19. It is necessary to conduct large-scale studies where the indications for using GCs are clearly defined together with the consistent timing, dose, and duration of treatment.

\section{Anti-cytokine therapy}

Some patients with SARS-CoV-2 infection develop pulmonary complications that can progress into ARDS and even more serious extrapulmonary systemic hyperinflammation syndrome [138].

Numerous studies [57,61, 64, 139-142] have shown that hyperinflammation and cytokine storms, as well as increased levels of pro-inflammatory cytokines IL-6, -8, $-2,-10$, TNF- $\alpha$, and IFN- $\alpha$, correlate with the severity of COVID-19 and poor outcomes.

Monoclonal antibodies to IL-6. Following reports that IL-6 is a critical factor of the cytokine storm associated with COVID-19, monoclonal antibodies against IL- 6 have been proposed as a therapeutic agent [141]. Clinical studies are underway to evaluate the efficacy of therapy with monoclonal antibodies against IL6R (tocilizumab, sarilumab, siltuximab) in pneumonia caused by COVID-19. Currently, only preliminary results are available.

Thus, Perrone et al. [143] showed that tocilizumab reduced the 30 -day mortality with no significant toxic effects in patients who did not initially require mechanical ventilation. $\mathrm{Xu}$ et al. [144] studied patients with COVID-19 who received a single dose of tocilizumab combined with lopinavir, methylprednisolone, and oxygen therapy. Tocilizumab restored lymphocyte counts in 10 out of 20 patients and resolved pneumonia in 19 out of 20 patients (as determined by chest CT). All patients showed improved symptoms and there were not any secondary pulmonary infections.

In a retrospective study [145], a link was found between therapy with tocilizumab and a decrease in the likelihood of admission to the intensive care unit, as well as the need for mechanical ventilation. However, no significant reduction in mortality was observed in 30 patients with severe pneumonia associated with COVID-19.

It is reported [146] that phase III of the ongoing largescale trial of sarilumab will be continued only in the "critical" group of patients (with improved outcomes) and not in the "severe" group.

In Russia, as it was recommended, targeted therapy with IL-6 inhibitors (tocilizumab, sarilumab) or IL-1 (canakinumab) in combination with GCs should be initiated to suppress the cytokine storm and prevent the development of severe lung damage and multiple organ failure [147].

Granulocyte-macrophage colony-stimulating factor (GM-CSF) is a hematopoietic growth factor and a key mediator of tissue inflammation. GM-CSF has several cellular sources, including monocytes, macrophages, $T$ cells, B cells, neutrophils, and tissue-resident cells [148]. GM-CSF has multiple pro-inflammatory effects on myeloid cells, including macrophages, monocytes, and neutrophils, by transmitting signals through the GM-CSF- $\alpha / \beta$ receptor complex that is expressed on myeloid cells. GM-CSF stimulates survival and facilitates polarization of the pro-inflammatory phenotypes of monocytes/macrophages, which primarily produce proinflammatory cytokines, including TNF- $\alpha, \mathrm{IL}-1 \beta$, and IL-6. GM-CSF also increases the survival rate of neutrophils, stimulates their oxidative burst, enhances phagocytosis, promotes the adhesion of neutrophils to endothelial cells, and the transfer of neutrophils to inflammation sites [148]. GM-CSF is not detected in the healthy people's circulating blood, but it was detected in the plasma of some patients hospitalized with COVID-19 [32]. It has been shown that the therapeutic inhibition of GM-CSF signaling by mavrilimumab in patients with rheumatoid arthritis reduces the level of IL-6 in the blood serum and indirectly 
suppresses the activation of $\mathrm{T}$ cells [149]. Treating patients with severe lung damage caused by COVID-19 using mavrilimumab - the monoclonal antibody to the GM-CSF receptor - resulted in good tolerability and clinical benefit (reduced fever and improved oxygenation).

Blocking GM-CSF can prevent immunopathology caused by the virus. The efficacy and safety of mavrilimumab and otilimab for COVID-19-associated lung damage are currently under study.

Janus kinases regulate signal transduction into immune cells. Inhibition of cytokine production and Janus kinase activity by low molecular weight synthetic drugs makes it possible to block the cytokine storm [147]. It was found that the Janus kinase inhibitor baricitinib had the ability to inhibit the production of IL-6 [150]. However, this agent can lead to an increase in the number of NK cells, as it is shown among patients with rheumatoid arthritis treated with baricitinib [151], and, thus, adversely affect the condition of patients with severe COVID-19. Clinical trials of baricitinib, tofacitinib, and ruxolitinib in moderate COVID-19 patients are ongoing.

According to recommendations adopted in Russia, the use of Janus kinase inhibitors - baricitinib and tofacitinib - is possible for moderate pneumonia in order to suppress hyperinflammation and prevent the development of serious lung and other organ damage caused by COVID-19 [147].

Anakinra. Nod-like receptors play an important role in the innate immunity: they protect the body from a wide range of pathogens, including RNA viruses [152]. It is known that SARS-CoV induces the nod-like receptor NLRP3, which in turn stimulates caspase-1, a molecule involved in the activation and massive release of IL-1 $\beta$ and IL-18 [153]. These two can be successfully inhibited by anakinra, a recombinant antagonist of human IL-1 [154]. A study is underway (NCT04339712, NCT04330638) to test different dosing regimens of anakinra in COVID-19: from $100 \mathrm{mg} /$ day subcutaneously for 28 days to $400-600 \mathrm{mg} /$ day intravenously for 5-7 days.

Colchicine is used to treat gout and familial Mediterranean fever. In recent years this drug has been used in the treatment of cardiovascular diseases to reduce the risk of ischemic complications [155]. A possible mechanism of action of colchicine in COVID-19 is its effect on cell adhesion molecules and inflammatory chemokines. Colchicine can inhibit the activation of NLRP3 in the inflammasome and also directly inhibit the synthesis of TNF- $\alpha$ and IL-6 [156]. Colchicine binds to the intracellular protein tubulin, which prevents the virus penetration into the cell nucleus and its subsequent replication; as a result, the viral load decreases [157]. The GRECCO-19 randomized study showed that treatment of patients with COVID-19 with colchicine helped reduce the time needed for normalization of the clinical condition, although no significant decrease in CRP levels was found [156].
The COLCORONA study [158] reported that the use of colchicine in outpatients with COVID-19 reduced the risk of hospitalization by $25 \%$, death by $44 \%$, and the need for ventilation by $50 \%$.

Studies, including those in Russia, continue to test the efficacy of conventional therapeutic doses of colchicine in the treatment of COVID-19 (NCT04322682, NCT04328480, NCT04326790, NCT04403243).

Immune checkpoint inhibitors. In recent years there is an increasing therapeutic use of immune checkpoint inhibitors (ICls) - antibodies that block the cytotoxic T-lymphocyte-associated protein 4 (CTLA-4), the protein of programmed cell death 1 (PD-1), and the ligand of programmed cell death receptor (PD-L1) [159]. Data on COVID-19-associated morbidity and mortality in cancer patients receiving $\mathrm{ICls}$ are conflicting. A number of authors [160-162] noted that no increased susceptibility to SARS-CoV-2 infection was observed in these patients.

A growing body of evidence suggests that ICls may be instrumental in treating viral infections by preventing T cell depletion. However, some cancer patients receiving $\mathrm{ICls}$ require immune-suppressive therapy for autoimmune side effects, which in turn may aggravate the course of SARS-CoV-2 infection. In this regard, further research is needed to assess the effectiveness of this therapy in patients with COVID-19.

\section{Mesenchymal stem cells}

Multipotent mesenchymal stem cells (MSCs) are present in most human tissues, including the umbilical cord. It is assumed that MSCs can reduce acute lung injury and inhibit the cell-mediated inflammatory response caused by SARS-CoV-2. MSCs lack the ACE2 receptor (used by the coronavirus to enter cells); therefore, they are resistant to infection [163, 164].

A pilot clinical study from China on intravenous MSCs transplantation involved 10 patients with confirmed COVID-19. Seven patients (1 with critically severe course, 4 with severe, and 2 with moderate COVID-19) received MSCs; 3 patients in serious condition placebo. All patients who received MSCs recovered. Among the patients in the control group, one individual died, one developed ARDS, and one remained in a stable serious condition [165]. In another pilot study [166] 29 patients with severe COVID-19 received standard therapy (oxygen, umifenovir/oseltamivir, antibiotics as indicated, and $\mathrm{GC}$ ); 12 patients received the same standard therapy and infusion of human umbilical cord MSCs (hUC-MSC). All patients who received hUC-MSC recovered and did not require mechanical ventilation. In 4 patients on standard therapy only, the condition worsened, they required mechanical ventilation, three of them died. However, the results are not statistically significant because the sample size was small.

In summary, it should be emphasized that an excessive inflammatory response with signs of a cytokine storm aggravates the course and worsens the 


\section{REVIEWS}

prognosis in COVID-19. Numerous studies on SARSCoV-2 and subsequent hyperinflammation are currently underway [167]. Medications used in daily rheumatologic practice may represent potential therapeutic options for COVID-19 due not only to their anti-inflammatory effect but also to some of their inherent antiviral properties.

\section{Prophylactic vaccines}

SARS-CoV-2 is a new virus; therefore, the duration of protective immunity after infection is yet to be determined, although there is a possibility of a rapid decline in natural immunity [168].

A problem of vaccination against SARS-CoV-2 is that the vaccine-induced immune response can cause an acute reaction to the vaccine itself or an increase in infection severity upon contact with the virus; this mechanism could develop through an increase in $\mathrm{T}$ cells and antibody-dependent amplification syndrome [169]. In addition, some viruses use antibodies to enter target cells [170-172]. An increase in morbidity in vaccinated individuals who contracted an infection has already been observed, for example, with measles, respiratory syncytial virus, and Dengue virus [173-175].

By now the following types of vaccines against SARS-
CoV-2 have been developed and undergo preclinical and clinical studies: inactivated; live attenuated; protein subunit; vector; based on synthetic virus-like particles, based on nucleic acids - DNA and RNA [168, 176, 177] (see the Table).

Most of the vaccines target the $S$ protein of SARSCoV-2. However, previous experience shows that the nucleocapsid $(\mathrm{N})$ of the coronavirus is also immunogenic - antibodies against the $\mathrm{N}$ protein of SARS-CoV-1 are formed in a higher titer and persist longer than antibodies against protein $S$ in recovered patients [178]. It is unknown if $\mathrm{N}$ protein is a potential protective immunogen for SARS-CoV-2, although vaccine formulations using the whole virus (inactivated, live attenuated vaccine) would potentially include $\mathrm{N}$ protein.

The first vaccine approved by WHO was BNT162b2 (Pfizer, Inc., USA and BioNTech, Germany). It consists of lipid nanoparticles modified with nucleosides of mRNA encoding the glycoprotein S of the SARS-CoV-2 virus [179].

Preclinical tests have shown both cellular and humoral immune responses against SARS-CoV-2 in mice [180] and humans (clinical phase I/II) - the formation of neutralizing antibodies upon a single vaccine administration [181]. A randomized phase II/III

\section{Best known vaccine preparations (based on [168] and [177])}

\begin{tabular}{|c|c|c|c|}
\hline Types of vaccines & Name and manufacturer & Targeted viral antigen & $\begin{array}{l}\text { WHO application } \\
\text { status }\end{array}$ \\
\hline \multirow[t]{3}{*}{ mRNA-based } & BNT162b2 (Pfizer, Inc., USA and BioNTech, Germany) & Spike & Approved \\
\hline & mRNA-1273 (Moderna, USA) & Stabilized spike & Approved \\
\hline & $\begin{array}{l}\text { Zorecimeran (INN) concentrate and solvent for dispersion } \\
\text { for injection (CureVac, Germany) }\end{array}$ & Spike & Under consideration \\
\hline \multirow[t]{4}{*}{ Vector } & AZD1222 (AstraZeneca and University of Oxford, UK) & Spike & Approved \\
\hline & $\begin{array}{l}\text { Ad26.COV2.S (Janssen Pharmaceutica of Johnson } \\
\text { \& Johnson, Belgium, USA) }\end{array}$ & Spike & Approved \\
\hline & Sputnik V (The Gamaleya National Center, Russia) & Spike & Under consideration \\
\hline & Ad5-nCoV (CanSinoBIO, China) & Spike & Under consideration \\
\hline \multirow[t]{4}{*}{ Protein-based } & $\begin{array}{l}\text { EpiVacCorona (State Scientific Center of Virology } \\
\text { and Biotechnology "Vector" of Rospotrebnadzor, Russia) }\end{array}$ & Multiple epitopes & Under consideration \\
\hline & $\begin{array}{l}\text { Recombinant Novel Coronavirus Vaccine (CHO Cell) } \\
\text { (Zhifei Longcom, China) }\end{array}$ & RBD dimer & Under consideration \\
\hline & SCB-2019 (Clover Biopharmaceuticals, China) & $\begin{array}{l}\text { Trimeric S protein } \\
\text { with alum adjuvant }\end{array}$ & Under consideration \\
\hline & $\begin{array}{l}\text { Cuba Soberana 01, Soberana } 02 \text {, Soberana Plus } \\
\text { (BioCubaFarma, Cuba) }\end{array}$ & Protein subunits & Under consideration \\
\hline \multirow[t]{4}{*}{ Inactivated } & $\begin{array}{l}\text { SARS-CoV-2 Vaccine (Vero Cell), Inactivated (InCoV) } \\
\text { (Sinopharm/Beijing Bio-Institute of Biological Products Co-Ltd, } \\
\text { China) }\end{array}$ & Whole virus & Approved \\
\hline & SARS-CoV-2 Vaccine (Vero Cell), Inactivated (Sinovac, China) & Whole inactivated virus & Under consideration \\
\hline & COVAXIN (Bharat Biotech, India) & Whole virus & Under consideration \\
\hline & $\begin{array}{l}\text { Inactivated SARS-CoV-2 Vaccine (Vero Cell) (Sinopharm/ } \\
\text { Wuhan Institute of Biological Products Co-Ltd, China) }\end{array}$ & Whole virus & Under consideration \\
\hline Virus-like particles/nanoparticles & NVX-CoV2373/Covovax (Novavax, USA) & Spike & Under consideration \\
\hline
\end{tabular}


trial of 43,548 people showed that a two-dose regimen of BNT162b2 provided $95 \%$ protection against COVID-19 in people aged 16 and over. The 2-month safety of the vaccine was similar to that of other antiviral vaccines [182].

The second and third vaccines were developed by AstraZeneca and the University of Oxford (UK); those are produced in South Korea and India. AZD1222 is a vector vaccine based on the ChAdOx1 chimpanzee adenovirus carrying the coronavirus $S$ protein gene. Preliminary results from the phase I/II study showed that seroconversion of neutralizing antibodies was observed in $91 \%$ of cases after one dose and $100 \%$ after two doses of the vaccine. An IFN-y response has also been reported [183]. Humoral responses to the SARSCoV-2 spike protein peaked on day 28 after vaccination and cellular responses were detected in all participants on day 14. Neutralizing antibodies were produced in all participants after the second dose of the vaccine. In addition, strong cellular and humoral immunogenicity was observed. Local and systemic adverse reactions of mild to moderate severity (pain at the injection site, chills, malaise, and headache) peaked on the first day of vaccination and were controlled with paracetamol [183].

The fourth vaccine which was recommended by WHO for use in emergencies is a single-ingredient preparation from Janssen Pharmaceutica of Johnson \& Johnson (Belgium, USA).

According to the interim results of phase III clinical trials, the efficacy of the vector vaccine Ad26.COV2.S at a single dose was $66.1 \%$, as assessed by preventing moderate and severe/critical forms of the disease and $85 \%$ in preventing severe/critical forms of the disease among all study participants from different regions, 28 days after vaccination. Anti-viral protection appears already on the $14^{\text {th }}$ day of vaccination [184].

The next (fifth) vaccine approved by WHO was mRNA1273 (Moderna, USA) based on mRNA. Preclinical studies showed that it effectively protected mice against the virus [185]. In phase I of clinical trials, the vaccine showed immunogenicity and $100 \%$ seroconversion after the second dose [186]; the antibody titer increased with an increase in the administered dose. According to the results of a phase III study, the mRNA-1273 vaccine is 94.1\% effective in preventing COVID-19. Mild, moderate, and severe systemic side effects have been identified; as reported, their severity significantly increases with the second vaccination and/or with the use of high doses of the vaccine. Antigen-specific T cells were most often found in the 100- $\mu \mathrm{g}$ vaccine group [187].

The sixth agent approved by the WHO against SARSCoV-2 is the Vero Cell vaccine (Sinopharm, China) based on inactivated coronavirus. Phase III trials showed that its efficacy in preventing symptomatic disease and hospitalization is $79 \%$ for all age groups, which is lower than that of Pfizer or Moderna [188].

Three vaccines have been currently registered in Russia: Sputnik V (National Research Centre for
Epidemiology and Microbiology named after Honorary Academician N.F. Gamaleya), EpiVacCorona (State Scientific Center of Virology and Biotechnology "Vector" of Rospotrebnadzor), and CoviVac (Chumakov Federal Scientific Center for Research and Development of Immune-and-Biological Products of Russian Academy of Sciences).

Sputnik V (Gam-COVID-Vac/Sputnik V) is a vector vaccine based on two different adenoviral vectors, Ad26 and Ad5 [189].

The results of phase I and II clinical trials show that Sputnik $V$ is highly immunogenic and elicits strong humoral and cellular immune responses in $100 \%$ of healthy adult volunteers, while the antibody titers in vaccinated participants are higher than those in COVID-19 convalescents. The most common side effects were pain at the injection site $(58 \%)$, fever $(50 \%)$, headache $(42 \%)$, asthenia (28\%), and muscle/joint pain (24\%). Most adverse events were mild and less pronounced with the administration of the freeze-dried vaccine [189].

An interim analysis of phase III clinical trials showed that the vaccine efficacy was $91.6 \%$ (95\% Cl 85.6-95.2), including people over 60 years old. According to [190], Sputnik V protects $100 \%$ against moderate and severe COVID-19.

The EpiVacCorona vaccine consists of chemically synthesized peptides identical to the $S$ protein immunogens of the SARS-CoV-2 coronavirus, conjugated to a carrier protein, and adsorbed on aluminum hydroxide. The results of phase I and II clinical trials showed that in $100 \%$ of volunteers, vaccination caused the development of antibodies specific to the antigens that make up the vaccine. Seroconversion (with a neutralizing antibody titer $\geq 1: 20$ ) was confirmed in $100 \%$ of cases 21 days after the second vaccination [191].

CoviVac is the latest Russian development based on the platform of inactivated children's poliomyelitis vaccine. CoviVac not only blocks the viral $S$ protein but mimics the body's natural process of fighting the virus. The CoviVac preparation is based on the whole virus, therefore, it is effective against most variants or mutations of SARS-CoV-2 [192].

Recent publications have revealed evidence of the so-called trained immunity that could protect against COVID-19. This principle is based on the non-specific enhancement of immune responses using the BCG vaccine (Mycobacterium bovis Bacillus CalmetteGuérin) or other bacterial components. The ability of BCG vaccine to induce "trained" immunity and stimulate antiviral immune response has been shown in animal experiments and clinical trials. Several countries are conducting randomized clinical trials in vulnerable populations to study the possibility of increasing protection against COVID-19 through BCG vaccination. In addition, it is important to determine which BCG strain and which vaccine can produce the strongest immunity $[193,194]$.

It is too early to draw conclusions on the effectiveness 
of anti-SARS-CoV-2 vaccines and their role in reducing the burden of the pandemic.

\section{Conclusion}

The rapid spread of SARS-CoV-2 and the outbreak of the pandemic around the world have become a reason for appearing of a large number of scientific papers shedding light on the immunology of the new coronavirus infection. In many of these publications, studies on the previous outbreaks of infections associated with SARS-CoV-1 and MERS-CoV have been taken into consideration. However, the immune responses to SARS-CoV-2 are different from those seen in other coronavirus infections. Thus, in contrast to the previous two pathogens, a large number of infected individuals remain asymptomatic, the incubation period lasts longer, and the transmission rate is higher than with other coronaviruses. Consequently, a clear understanding of the immunological aspects of the virus-host interaction is needed to develop means of effective treatment and prevention of COVID-19.

Authors' contribution: N.A. Lyubavina - study conceptualization and design, authoring the sections "Anti-inflammation therapy", "Anti-cytokine therapy", "Prophylactic vaccines", editing the manuscript; S.G. Saltsev - search and systematization of the literature; N.V. Menkov - authoring the section "Mesenchymal stem cells", editing the manuscript; L.V. Tyurikova - authoring the sections "Innate lymphoid cells", "Monocytes/macrophages and dendritic cells"; S.S. Plastinina - authoring the section "T-lymphocytes", editing the article; M.L. Shonia and A.A. Tulichev authoring the section "The use of neutralizing antibodies and convalescent plasma for COVID-19 therapy", editing the manuscript; M.Yu. Milyutina - authoring the section "Interferon therapy", editing the article; E.V. Makarova authoring the sections "Innate immune response", "Humoral immune response", critical reviewing and scientific editing of the manuscript.

Research funding. The study was supported by the Russian Foundation for Basic Research, grant No.20115-50332.

Conflicts of interest. There are no conflicts of interest related to this study.

\section{References}

1. WHO coronavirus disease (COVID-19) dashboard. URL: https://covid19.who.int.

2. Wu Z., McGoogan J.M. Characteristics of and important lessons from the coronavirus disease 2019 (COVID-19) outbreak in China: summary of a report of 72314 cases from the Chinese Center for Disease Control and Prevention. JAMA 2020; 323(13): 1239-1242, https://doi.org/10.1001/ jama.2020.2648.

3. de Wit E., van Doremalen N., Falzarano D., Munster V.J. SARS and MERS: recent insights into emerging coronaviruses. Nat Rev Microbiol 2016; 14(8): 523-534, https://doi.org/10.1038/nrmicro.2016.81.

4. Du L., He Y., Zhou Y., Liu S., Zheng B.J., Jiang S. The spike protein of SARS-CoV - a target for vaccine and therapeutic development. Nat Rev Microbiol 2009; 7(3): 226236, https://doi.org/10.1038/nrmicro2090.

5. Du L., Yang Y., Zhou Y., Lu L., Li F., Jiang S. MERSCoV spike protein: a key target for antivirals. Expert Opin Ther Targets 2017; 21(2): 131-143, https://doi.org/10.1080/ 14728222.2017.1271415.

6. Fauci A.S., Lane H.C., Redfield R.R. COVID-19 navigating the uncharted. N Engl J Med 2020; 382(13): 12681269, https://doi.org/10.1056/nejme2002387.

7. Kuba K., Imai Y., Rao S., Gao H., Guo F., Guan B., Huan Y., Yang P., Zhang Y., Deng W., Bao L., Zhang B., Liu G., Wang Z., Chappell M., Liu Y., Zheng D., Leibbrandt A., Wada T., Slutsky A.S., Liu D., Qin C., Jiang C., Penninger J.M. A crucial role of angiotensin converting enzyme 2 (ACE2) in SARS coronavirus-induced lung injury. Nat Med 2005; 11(8): 875-879, https://doi.org/10.1038/nm1267.

8. Guo Y., Korteweg C., McNutt M.A., Gu J. Pathogenetic mechanisms of severe acute respiratory syndrome. Virus Res 2008; 133(1): 4-12, https://doi.org/10.1016/j. virusres.2007.01.022.

9. Lukassen S., Chua L.R., Trefzer T., Kahn N.C., Schneider M.A., Muley T., Winter H., Meister M., Veith C., Boots A.W., Hennig B.P., Kreuter M., Conrad C., Eils R. SARSCoV-2 receptor ACE2 and TMPRSS2 are primarily expressed in bronchial transient secretory cells. EMBO J 2020; 39(10): e105114, https://doi.org/10.15252/embj.20105114.

10. Guzzi P.H., Mercatelli D., Ceraolo C., Giorgi F.M. Master regulator analysis of the SARS-CoV-2/human interactome. J Clin Med 2020; 9(4): 982, https://doi.org/10.3390/ jcm9040982.

11. Sokolowska M., Lukasik Z.M., Agache I., Akdis C.A., Akdis D., Akdis M., Barcik W., Brough H.A., Eiwegger T., Eljaszewicz A., Eyerich S., Feleszko W., Gomez-Casado C., Hoffmann-Sommergruber K., Janda J., Jiménez-Saiz R., Jutel M., Knol E.F., Kortekaas Krohn I., Kothari A., Makowska J., Moniuszko M., Morita H., O'Mahony L., Nadeau K., Ozdemir C., Pali-Schöll I., Palomares O., Papaleo F., Prunicki M., SchmidtWeber C.B., Sediva A., Schwarze J., Shamji M.H., TramperStranders G.A., van de Veen W., Untersmayr E. Immunology of COVID-19: mechanisms, clinical outcome, diagnostics, and perspectives - a report of the European Academy of Allergy and Clinical Immunology (EAACI). Allergy 2020; 75(10): 24452476, https://doi.org/10.1111/all.14462.

12. Channappanavar R., Fehr A.R., Vijay R., Mack M., Zhao J., Meyerholz D.K., Perlman S. Dysregulated type I interferon and inflammatory monocyte-macrophage responses cause lethal pneumonia in SARS-CoV-infected mice. Cell Host Microbe 2016; 19(2): 181-193, https://doi.org/10.1016/j. chom.2016.01.007.

13. Channappanavar R., Fehr A.R., Zheng J., WohlfordLenane C., Abrahante J.E., Mack M., Sompallae R., McCray P.B. Jr., Meyerholz D.K., Perlman S. IFN-I response timing relative to virus replication determines MERS coronavirus infection outcomes. J Clin Invest 2019; 129(9): 3625-3639, https://doi.org/10.1172/jci126363.

14. Blanco-Melo D., Nilsson-Payant B.E., Liu W.C., Uhl S., Hoagland D., Møller R., Jordan T.X., Oishi K., Panis M., Sachs D., Wang T.T., Schwartz R.E., Lim J.K., Albrecht R.A., tenOever B.R. Imbalanced host response to SARS-CoV-2 
drives development of COVID-19. Cell 2020; 181(5): 10361045, https://doi.org/10.1016/j.cell.2020.04.026.

15. Lokugamage K.G., Hage A., de Vries M., ValeroJimenez A.M., Schindewolf C., Dittmann M., Rajsbaum R., Menachery V.D. SARS-CoV-2 is sensitive to type I interferon pretreatment. bioRxiv 2020; 2020.03.07.982264, https://doi. org/10.1101/2020.03.07.982264.

16. Mantlo E.K., Bukreyeva N., Maruyama J., Paessler S., Huang C. Antiviral activities of type I interferons to SARSCoV-2 infection. Antiviral Res 2020; 179: 104811, https://doi. org/10.1016/j.antiviral.2020.104811.

17. Stanifer M.L., Kee C., Cortese M., Zumaran C.M., Triana S., Mukenhirn M., Kraeusslich H.G., Alexandrov T., Bartenschlager R., Boulant S. Critical role of type III interferon in controlling SARS-CoV-2 infection, replication and spread in primary human intestinal epithelial cells. Cell Reports 2020; 32(1): 197863, https://doi.org/10.1016/j.celrep.2020.107863.

18. Cameron M.J., Kelvin A.A., Leon A.J., Cameron C.M., Ran L., Xu L., Chu Y.K., Danesh A., Fang Y., Li Q., Anderson A., Couch R.C., Paquette S.G., Fomukong N.G., Kistner O., Lauchart M., Rowe T., Harrod K.S., Jonsson C.B., Kelvin D.J. Lack of innate interferon responses during SARS coronavirus infection in a vaccination and reinfection ferret model. PLoS One 2012; 7(9): e45842, https://doi.org/10.1371/ journal.pone.0045842.

19. Minakshi R., Padhan K., Rani M., Khan N., Ahmad F., Jameel S. The SARS coronavirus 3a protein causes endoplasmic reticulum stress and induces ligand-independent downregulation of the type 1 interferon receptor. PLoS One 2009; 4(12): e8342, https://doi.org/10.1371/journal.pone.0008342.

20. Wathelet M.G., Orr M., Frieman M.B., Baric R.S. Severe acute respiratory syndrome coronavirus evades antiviral signaling: role of nsp1 and rational design of an attenuated strain. J Virol 2007; 81(21): 11620-11633, https:// doi.org/10.1128/jvi.00702-07.

21. Spiegel M., Pichlmair A., Martínez-Sobrido L., Cros J., García-Sastre A., Haller O., Weber F. Inhibition of Beta interferon induction by severe acute respiratory syndrome coronavirus suggests a two-step model for activation of interferon regulatory factor 3. J Virol 2005; 79(4): 2079-2086, https://doi.org/10.1128/jvi.79.4.2079-2086.2005.

22. Lu X., Pan J., Tao J., Guo D. SARS-CoV nucleocapsid protein antagonizes IFN- $\beta$ response by targeting initial step of IFN- $\beta$ induction pathway, and its $C$-terminal region is critical for the antagonism. Virus Genes 2011; 42(1): 37-45, https://doi. org/10.1007/s11262-010-0544-x.

23. Hadjadj J., Yatim N., Barnabei L., Corneau A., Boussier J., Péré H., Charbit B., Bondet V., ChenevierGobeaux C., Breillat P., Carlier N., Gauzit R., Morbieu C., Pène F., Marin N., Roche N., Szwebel T.A., Merkling S.H., Treluyer J.M., Veyer D., Mouthon L., Blanc C., Tharaux P.L., Rozenberg F., Fischer A., Duffy D., Rieux-Laucat F., Kernéis S., Terrier B. Impaired type I interferon activity and exacerbated inflammatory responses in severe COVID-19 patients. Science 2020; 369(6504): 718-724, https://doi.org/10.1126/science. abc6027.

24. Li J., Guo M., Tian X., Liu C., Wang X., Yang X., Wu P., Xiao Z., Qu Y., Yin Y., Wang C., Zhang Y., Zhu Z., Liu Z., Peng C., Zhu T., Liang Q. Virus-host interactome and proteomic survey of PMBCs from COVID-19 patients reveal potential virulence factors influencing SARS-CoV-2 pathogenesis. Med (NY) 2021; 2(1): 99-112.e7, https://doi. org/10.1016/j.medj.2020.07.002.
25. Travaglini K.J., Nabhan A.N., Penland L., Sinha R., Gillich A., Sit R.V., Chang S., Conley S.D., Mori Y., Seita J., Berry G.J., Shrager J.B., Metzger R.J., Kuo C.S., Neff N., Weissman I.L., Quake S.R., Krasnow M.A. A molecular cell atlas of the human lung from single cell RNA sequencing. Nature 2020; 587(78350): 619-625, https://doi.org/10.1038/ s41586-020-2922-4.

26. Liu J., Li S., Liu J., Liang B., Wang X., Wang H., Li W., Tong Q., Yi J., Zhao L., Xiong L., Guo C., Tian J., Luo J., Yao J., Pang R., Shen H., Peng C., Liu T., Zhang Q., Wu J., Xu L., Lu S., Wang B., Weng Z., Han C., Zhu H., Zhou R., Zhou H., Chen X., Ye P., Zhu B., Wang L., Zhou W., He S., He Y., Jie S., Wei P., Zhang J., Lu Y., Wang W., Zhang L., Li L., Zhou F., Wang J., Dittmer U., Lu M., Hu Y., Yang D., Zheng $X$. Longitudinal characteristics of lymphocyte responses and cytokine profiles in the peripheral blood of SARS-CoV-2 infected patients. EBioMedicine 2020; 55: 102763, https://doi. org/10.1016/j.ebiom.2020.102763.

27. Wang F., Nie J., Wang H., Zhao Q., Xiong Y., Deng L., Song S., Ma Z., Mo P., Zhang Y. Characteristics of peripheral lymphocyte subset alteration in COVID-19 pneumonia. J Infect Dis 2020; 221(11): 1762-1769, https://doi.org/10.1093/infdis/ jiaa150.

28. Qin C., Zhou L., Hu Z., Zhang S., Yang S., Tao Y., Xie C., Ma K., Shang K., Wang W., Tian D.S. Dysregulation of immune response in patients with coronavirus 2019 (COVID-19) in Wuhan, China. Clin Infect Dis 2020; 71(15): 762-768, https://doi.org/10.1093/cid/ciaa248.

29. Zheng M., Gao Y., Wang G., Song G., Liu S., Sun D., Xu Y., Tian Z. Functional exhaustion of antiviral lymphocytes in COVID-19 patients. Cell Mol Immunol 2020; 17(5): 533-535, https://doi.org/10.1038/s41423-020-0402-2.

30. National Research Project for SARS; Beijing Group. The involvement of natural killer cells in the pathogenesis of severe acute respiratory syndrome. Am J Clin Pathol 2004; 121(4): 507-511, https://doi.org/10.1309/wpk7-y2xk-nf4c-bf3r.

31. Wilk A.J., Rustagi A., Zhao N.Q., Roque J., MartínezColón G.J., McKechnie J.L., Ivison G.T., Ranganath T., Vergara R., Hollis T., Simpson L.J., Grant P., Subramanian A., Rogers A.J., Blish C.A. A single-cell atlas of the peripheral immune response to severe COVID-19. Nature Medicine 2020; 26(7): 1070-1076, https://doi.org/10.1038/s41591-020-0944-y.

32. Huang C., Wang Y., Li X., Ren L., Zhao J., Hu Y., Zhang L., Fan G., Xu J., Gu X., Cheng Z., Yu T., Xia J., Wei Y., Wu W., Xie X., Yin W., Li H., Liu M., Xiao Y., Gao H., Guo L., Xie J., Wang G., Jiang R., Gao Z., Jin Q., Wang J., Cao B. Clinical features of patients infected with 2019 novel coronavirus in Wuhan, China. Lancet 2020; 395(10223): 497506, https://doi.org/10.1016/s0140-6736(20)30183-5.

33. Wang W., Liu X., Wu S., Lie P., Huang L., Li Y., Cheng L., Chen S., Nong L., Lin Y., He J. The definition and risks of cytokine release syndrome-like in 11 COVID-19infected pneumonia critically ill patients: disease characteristics and retrospective analysis. medRxiv 2020; 222(9): 1444-1451, https://doi.org/10.1101/2020.02.26.20026989.

34. Cifaldi L., Prencipe G., Caiello I., Bracaglia C., Locatell F., De Benedetti F., Strippoli R. Inhibition of natural killer cell cytotoxicity by interleukin-6: implications for the pathogenesis of macrophage activation syndrome. Arthritis Rheumatol 2015; 67(11): 3037-3046, https://doi.org/10.1002/art.39295.

35. Lee J., Lee S.H., Shin N., Jeong M., Kim M.S., Kim M.J., Yoon S.R., Chung J.W., Kim T.D., Choi I. Tumor necrosis factor- $\alpha$ enhances IL-15-induced natural killer cell 
differentiation. Biochem Biophys Res Commun 2009; 386(4): 718-723, https://doi.org/10.1016/j.bbrc.2009.06.120.

36. Guo C., Li B., Ma H., Wang X., Cai P., Yu Q., Zhu L., Jin L., Jiang C., Fang J., Liu Q., Zong D., Zhang W., Lu Y., Li K., Gao X., Fu B., Liu L., Ma X., Weng J., Wei H., Jin T., Lin J., Qu K. Single-cell analysis of two severe COVID-19 patients reveals a monocyte-associated and tocilizumabresponding cytokine storm. Nat Commun 2020; 11(1): 3924, https://doi.org/10.1038/s41467-020-17834-w.

37. Liao M., Liu Y., Yuan J., Wen Y., Xu G., Zhao J., Cheng L., Li J., Wang X., Wang F., Liu L., Amit I., Zhang S., Zhang Z. Single-cell landscape of bronchoalveolar immune cells in patients with COVID-19. Nature Medicine 2020, 26: 842-844, https://doi.org/10.1038/s41591-020-0901-9.

38. Chen I.Y., Moriyama M., Chang M.F., Ichinohe T. Severe acute respiratory syndrome coronavirus viroporin $3 a$ activates the NLRP3 inflammasome. Front Microbiol 2019; 10: 50, https://doi.org/10.3389/fmicb.2019.00050.

39. Zhou Y., Fu B., Zheng X., Wang D., Zhao C., Qi Y., Sun R., Tian Z., Xu X., Wei H. Pathogenic T-cells and inflammatory monocytes incite inflammatory storms in severe COVID-19 patients. National Sci Rev 2020; 7(6): 998-1002, https://doi.org/10.1093/nsr/nwaa041.

40. McGonagle D., Sharif K., O'Regan A., Bridgewood C. The role of cytokines including interleukin- 6 in COVID-19 induced pneumonia and macrophage activation syndromelike disease. Autoimmun Rev 2020; 19(6): 102537, https://doi. org/10.1016/j.autrev.2020.102537.

41. Nairz M., Theurl I., Swirski F.K., Weiss G. "Pumping iron" - how macrophages handle iron at the systemic, microenvironmental, and cellular levels. Pflugers Arch 2017; 469(3-4): 397-418, https://doi.org/10.1007/s00424-017-1944-8.

42. Velavan T.P., Meyer C.G. Mild versus severe COVID-19: laboratory markers. Int J Infect Dis 2020; 95: 304-307, https:// doi.org/10.1016/j.ijid.2020.04.061.

43. Giamarellos-Bourboulis E.J., Netea M.G., Rovina N., Akinosoglou K., Antoniadou A., Antonakos N., Damoraki G., Gkavogianni T., Adami M.E., Katsaounou P., Ntaganou M., Kyriakopoulou M., Dimopoulos G., Koutsodimitropoulos I., Velissaris D., Koufargyris P., Karageorgos A., Katrini K., Lekakis V., Lupse M., Kotsaki A., Renieris G., Theodoulou D., Panou V., Koukaki E., Koulouris N., Gogos C., Koutsoukou A. Complex immune dysregulation in COVID-19 patients with severe respiratory failure. Cell Host Microbe 2020; 27(6): 992 1000, https://doi.org/10.1016/j.chom.2020.04.009.

44. Zhou Y., Fu B., Zheng X., Wang D., Zhao C., Qi Y., Sun R., Tian Z., Xu X., Wei H. Aberrant pathogenic GM-CSF ${ }^{+} T$ cells and inflammatory $\mathrm{CD} 14^{+} \mathrm{CD} 16^{+}$monocytes in severe pulmonary syndrome patients of a new coronavirus. Natl Sci Rev 2020; 7(6): 998-1002, https://doi.org/10.1101/2020.02.12.945576.

45. Mehta P., McAuley D.F., Brown M., Sanchez E., Tattersall R.S., Manson J.J.; HLH Across Speciality Collaboration, UK. COVID-19: consider cytokine storm syndromes and immunosuppression. Lancet 2020; 395(10229): 1033-1034, https://doi.org/10.1016/s0140-6736(20)30628-0.

46. Prokunina-Olsson L., Alphonse N., Dickenson R.E., Durbin J.E., Glenn J.S., Hartmann R., Kotenko S.V., Lazear H.M., O'Brien T.R., Odendall C., Onabajo O.O., Piontkivska H., Santer D.M., Reich N.C., Wack A., Zanoni I. COVID-19 and emerging viral infections: the case for interferon lambda. J Exp Med 2020; 217(5): e20200653, https://doi. org/10.1084/jem.20200653.

47. Tanaka T., Narazaki M., Kishimoto T. Immunotherapeutic implications of IL-6 blockade for cytokine storm. Immunotherapy 2016; 8(8): 959-970, https://doi.org/10.2217/imt-2016-0020.

48. Barnes B.J., Adrover J.M., Baxter-Stoltzfus A., Borczuk A., Cools-Lartigue J., Crawford J.M., DaßlerPlenker J., Guerci P., Huynh C., Knight J.S., Loda M., Looney M.R., McAllister F., Rayes R., Renaud S., Rousseau S., Salvatore S., Schwartz R.E., Spicer J.D., Yost C.C., Weber A., Zuo Y., Egeblad M. Targeting potential drivers of COVID-19: neutrophil extracellular traps. J Exp Med 2020; 217(6), e20200652, https://doi.org/10.1084/jem.20200652.

49. Yi Y., Lagniton P.N.P., Ye S., Li E., Xu R.H. COVID-19: what has been learned and to be learned about the novel coronavirus disease. Int J Biol Sci 2020; 16(10): 1753-1766, https://doi.org/10.7150/ijbs.45134.

50. Chen J., Lau Y.F., Lamirande E.W., Paddock C.D., Bartlett J.H., Zaki S.R., Subbarao K. Cellular immune responses to severe acute respiratory syndrome coronavirus (SARS-CoV) infection in senescent BALB/c mice: $\mathrm{CD}^{+}$ $T$ cells are important in control of SARS-CoV infection. $J$ Virol 2010; 84(3): 1289-1301, https://doi.org/10.1128/jvi.01281-09.

51. Yang Y., Xiong Z., Zhang S., Yan Y., Nguyen J., Ng B., Lu H., Brendese J., Yang F., Wang H., Yang X.F. Bcl-xL inhibits T-cell apoptosis induced by expression of SARS coronavirus $E$ protein in the absence of growth factors. Biochem J 2005; 392(Pt 1): 135-143, https://doi.org/10.1042/bj20050698.

52. Cron R.Q., Chatham W.W. The rheumatologist's role in COVID-19. J Rheumato 2020; 47(5): 639-642, https://doi. org/10.3899/jrheum.200334.

53. He Z., Zhao C., Dong Q., Zhuang H., Song S., Peng G., Dwyer D.E. Effects of severe acute respiratory syndrome (SARS) coronavirus infection on peripheral blood lymphocytes and their subsets. Int J Infect Dis 2005; 9(6): 323-330, https:// doi.org/10.1016/j.ijid.2004.07.014.

54. Chen G., Wu D., Guo W., Cao Y., Huang D., Wang H., Wang T., Zhang X., Chen H., Yu H., Zhang X., Zhang M., Wu S., Song J., Chen T., Han M., Li S., Luo X., Zhao J., Ning Q. Clinical and immunological features of severe and moderate coronavirus disease 2019. J Clin Invest 2020; 130(5): 2620-2629, https://doi.org/10.1172/jci137244.

55. Nie S., Zhao X., Zhao K., Zhang Z., Zhang Z., Zhang Z. Metabolic disturbances and inflammatory dysfunction predict severity of coronavirus disease 2019 (COVID-19): a retrospective study. medRxiv 2020, https://doi.org/10.1101/ 2020.03.24.20042283.

56. Zeng Q., Li Y.Z., Huang G., Wu W., Dong S.Y., Xu Y. Mortality of COVID-19 is associated with cellular immune function compared to immune function in Chinese Han population. medRxiv 2020, https://doi.org/10.1101/2020.03.08. 20031229.

57. Diao B., Wang C., Tan Y., Chen X., Liu Y., Ning L., Chen L., Li M., Liu Y., Wang G., Yuan Z., Feng Z., Zhang Y., Wu Y., Chen $Y$. Reduction and functional exhaustion of $T$ cells in patients with coronavirus disease 2019 (COVID-19). Front Immunol 2020; 11: 827, https://doi.org/10.3389/fimmu.2020.00827.

58. Thevarajan I., Nguyen T.H.O., Koutsakos M., Druce J., Caly L., van de Sandt C.E., Jia X., Nicholson S., Catton M., Cowie B., Tong S.Y.C., Lewin S.R., Kedzierska K. Breadth of concomitant immune responses prior to patient recovery: a case report of non-severe COVID-19. Nat Med 2020; 26(4): 453-455, https://doi.org/10.1038/s41591-020-0819-2.

59. Liu B., Han J., Cheng X., Yu L., Zhang L., Wang W., Ni L., Wei C., Huang Y., Cheng Z. Persistent SARS-CoV-2 presence is companied with defects in adaptive immune 
system in non-severe COVID-19 patients. medRxiv 2020, https://doi.org/10.1101/2020.03.26.20044768.

60. Chu H., Zhou J., Wong B.H., Li C., Chan J.F., Cheng Z.S., Yang D., Wang D., Lee A.C., Li C., Yeung M.L., Cai J.P., Chan I.H.Y., Ho W.K., To K.K.W., Zheng B.Z., Yao Y., Qin C., Yuen K.Y. Middle East respiratory syndrome coronavirus efficiently infects human primary $T$ lymphocytes and activates the extrinsic and intrinsic apoptosis pathways. J Infect Dis 2016; 213(6): 904-914, https://doi.org/10.1093/ infdis/jiv380.

61. Wan S., Yi Q., Fan S., Lv J., Zhang X., Guo L., Lang C., Xiao Q., Xiao K., Yi Z., Qiang M., Xiang J., Zhang B., Chen Y. Characteristics of lymphocyte subsets and cytokines in peripheral blood of 123 hospitalized patients with 2019 novel coronavirus pneumonia (NCP). medRxiv 2020, https://doi.org/ 10.1101/2020.02.10.20021832.

62. Kamphuis E., Junt T., Waibler Z., Forster R., Kalinke U. Type I interferons directly regulate lymphocyte recirculation and cause transient blood lymphopenia. Blood 2006; 108(10): 3253-3261, https://doi.org/10.1182/blood-2006-06-027599.

63. Shiow L.R., Rosen D.B., Brdicková N., Xu Y., An J., Lanier L.L., Cyster J.G., Matloubian M. CD69 acts downstream of interferon- $\alpha / \beta$ to inhibit $S 1 \mathrm{P}_{1}$ and lymphocyte egress from lymphoid organs. Nature 2006; 440(7083): 540-544, https:// doi.org/10.1038/nature04606.

64. Xu Z., Shi L., Wang Y., Zhang J., Huang L., Zhang C., Liu S., Zhao P., Liu H., Zhu L., Tai Y., Bai C., Gao T., Song J., Xia P., Dong J., Zhao J., Wang F.S. Pathological findings of COVID-19 associated with acute respiratory distress syndrome. Lancet Respir Med 2020; 8(4): 420-422, https://doi. org/10.1016/s2213-2600(20)30076-x.

65. Tian S., Xiong Y., Liu H., Niu L., Guo J., Liao M., Xiao S.Y. Pathological study of the 2019 novel coronavirus disease (COVID-19) through postmortem core biopsies. Mod Pathol 2020; 33(6): 1007-1014, https://doi.org/10.1038/ s41379-020-0536-X.

66. Walter J.M., Helmin K.A., Abdala-Valencia H., Wunderink R.G., Singer B.D. Multidimensional assessment of alveolar T cells in critically ill patients. JCI Insight 2018; 3(17): e123287, https://doi.org/10.1172/jci.insight.123287.

67. Lei L., Qian H., Yang X., Zhou X., Zhang X., Zhang D., Dai T., Guo R., Shi L., Cheng Y., Zhang B., Hu J., Guo Y. The phenotypic changes of $ү \delta$ T cells in COVID-19 patients. J Cell Mol Med 2020, 24(19): 11603-11606, https://doi.org/10.1111/ jcmm.15620.

68. Ni L., Ye F., Chen M.L., Feng Y., Deng Y.Q., Zhao H., Wei P., Ge J., Gou M., Li X., Sun L., Cao T., Wang P., Zhou C., Zhang R., Liang P., Guo H., Wang X., Qin C.F., Chen F., Dong C. Detection of SARS-CoV-2-specific humoral and cellular immunity in COVID-19 convalescent individuals. Immunity 2020; 52(6): 971-977.e3, https://doi.org/10.1016/j. immuni.2020.04.023.

69. Zheng H.Y., Zhang M., Yang C.X., Zhang N., Wang X.C., Yang X.P., Dong X.Q., Zheng Y.T. Elevated exhaustion levels and reduced functional diversity of $T$ cells in peripheral blood may predict severe progression in COVID-19 patients. Cell Mol Immunol 2020; 17(5): 541-543, https://doi. org/10.1038/s41423-020-0401-3.

70. Weiskopf D., Schmitz K.S., Raadsen M.P., Grifoni A., Okba N.M.A., Endeman H., van den Akker J.P.C., Molenkamp R., Koopmans M.P.G., van Gorp E.C.M., Haagmans B.L., de Swart R.L., Sette A., de Vries R.D. Phenotype of SARS-CoV-2-specific T-cells in COVID-19 patients with acute respiratory distress syndrome. Sci Immunol 2020; 5(48), https://doi.org/10.1101/2020.04.11.20062349.

71. Zhang G., Nie S., Zhang Z., Zhang Z. Longitudinal change of severe acute respiratory syndrome coronavirus 2 antibodies in patients with coronavirus disease 2019. J Infect Dis 2020; 222(2): 183-188, https://doi.org/10.1093/infdis/jiaa229.

72. Huang A.T., Garcia-Carreras B., Hitchings M.D.T., Yang B., Katzelnick L., Rattigan S.M., Borgert B., Moreno C., Solomon B.D., Rodriguez-Barraquer I., Lessler J., Salje H., Burke D., Wesolowski A., Cummings D.A.T. A systematic review of antibody mediated immunity to coronaviruses: antibody kinetics, correlates of protection, and association of antibody responses with severity of disease. Nat Commun 2020; 11(1): 4704, https://doi.org/10.1038/s41467-020-18450-4.

73. Yuan M., Liu H., Wu N.C., Wilson I.A. Recognition of the SARS-CoV-2 receptor binding domain by neutralizing antibodies. Biochem Biophys Res Commun 2021; 538: 192203, https://doi.org/10.1016/j.bbrc.2020.10.012.

74. To K.K., Tsang O.T., Leung W.S., Tam A.R., Wu T.C., Lung D.C., Yip C.C.Y., Cai J.P., Chan J.M.C., Chik T.S.H., Lau D.P.L., Choi C.Y.C., Chen L.L., Chan W.M., Chan K.H., Ip J.D., Ng A.C.K., Poon R.W.S., Luo C.T., Cheng V.C.C., Chan J.F.W., Hung I.F.N., Chen Z., Chen H., Yuen K.Y. Temporal profiles of viral load in posterior oropharyngeal saliva samples and serum antibody responses during infection by SARS-CoV-2: an observational cohort study. Lancet Infect Dis 2020; 20(5): 565-574, https://doi.org/10.1016/s1473-3099(20)30196-1.

75. Wu F., Wang A., Liu M., Wang Q., Chen J., Xia S., Ling Y., Zhang Y., Xun J., Lu L., Jiang S., Lu H., Wen Y., Huang J. Neutralizing antibody responses to SARS-CoV-2 in a COVID-19 recovered patient cohort and their implications. medRxiv 2020, https://doi.org/10.1101/2020.03.30.20047365.

76. Liu W., Fontanet A., Zhang P.H., Zhan L., Xin Z.T., Baril L., Tang F., Lv H., Cao W.H. Two-year prospective study of the humoral immune response of patients with severe acute respiratory syndrome. J Infect Dis 2006; 193(6): 792-795, https://doi.org/10.1086/500469.

77. Alshukairi A.N., Khalid I., Ahmed W.A., Dada A.M., Bayumi D.T., Malic L.S., Althawadi S., Ignacio K., Alsalmi H.S., Al-Abdely H.M., Wali G.Y., Qushmaq I.A., Alraddadi B.M., Perlman S. Antibody response and disease severity in healthcare worker MERS survivors. Emerg Infect Dis 2016; 22(6): 1113-1115, https://doi.org/10.3201/eid2206.160010.

78. Long Q.X., Liu B.Z. Deng H.J., Wu G.C., Deng K., Chen Y.K., Liao P., Qiu J.F., Lin Y., Cai X.F., Wang D.Q., Hu Y., Ren J.H., Tang N., Xu Y.Y., Yu L.H., Mo Z., Gong F., Zhang X.L., Tian W.G., Hu L., Zhang X.X., Xiang J.L., Du H.X., Liu H.W., Lang C.H., Luo X.H., Wu S.B., Cui X.P., Zhou Z., Zhu M.M., Wang J., Xue C.J., Li X.F., Wang L., Li Z.J., Wang K., Niu C.C., Yang Q.J., Tang X.J., Zhang Y., Liu X.M., Li J.J., Zhang D.C., Zhang F., Liu P., Yuan J., Li Q., Hu J.L., Chen J., Huang A.L. Antibody responses to SARS-CoV-2 in patients with COVID-19. Nat Med 2020; 26(6): 845-848, https://doi.org/10.1038/s41591-020-0897-1.

79. Guo L., Ren L., Yang S., Xiao M., Chang D., Yang F., Dela Cruz C.S., Wang Y., Wu C., Xiao Y., Zhang L., Han L., Dang S., Xu Y., Yang Q.W., Xu S.Y., Zhu H.D., Xu Y.C., Jin Q., Sharma L., Wang L., Wang J. Profiling early humoral response to diagnose novel coronavirus disease (COVID-19). Clin Infect Dis 2020; 71(15): 778-785, https://doi.org/10.1093/cid/ciaa310.

80. Wölfel R., Corman V.M., Guggemos W., Seilmaier M., Zange S., Müller M.A., Niemeyer D., Jones T.C., Vollmar P., Rothe C., Hoelscher M., Bleicker T., Brünink S., Schneider J., 
Ehmann R., Zwirglmaier K., Drosten C., Wendtner C. Virological assessment of hospitalized patients with COVID-2019. Nature 2020; 581(7809): 465-469, https://doi. org/10.1038/s41586-020-2196-x.

81. Lou B., Li T.D., Zheng S.F., Su Y.Y., Li Z.Y., Liu W., Yu F., Ge S.X., Zou Q.D., Yuan Q., Lin S., Hong C.M., Yao X.Y., Zhang X.J., Wu D.H., Zhou G.L., Hou W.H., Li T.T., Zhang Y.L., Zhang S.Y., Fan J., Zhang J., Xia N.S., Chen Y. Serology characteristics of SARS-CoV-2 infection since exposure and post symptom onset. Eur Respir J 2020; 56(2): 2000763, https://doi.org/10.1183/13993003.00763-2020.

82. Fafi-Kremer S., Bruel T., Madec Y., Grant R., Tondeur L., Grzelak L., Staropoli I., Anna F., Souque F., FernandesPellerin S., Jolly N., Renaudat C., Ungeheuer M.-N., SchmidtMutter C., Collongues N., Bolle A., Velay A., Lefebvre N., Mielcarek M., Meyer N., Rey D., Charneau P., Hoen B., De Seze J., Schwartz O., Fontanet A. Serologic responses to SARS-CoV-2 infection among hospital staff with mild disease in eastern France. EBioMedicine 2020; 59: 102915, https://doi. org/10.1016/j.ebiom.2020.102915.

83. Okba N.M.A., Müller M.A., Li W., Wang C., GeurtsvanKessel C.H., Corman V.M., Lamers M.M., Sikkema R.S., de Bruin E., Chandler F.D., Yazdanpanah Y., Hingrat Q.L., Descamps D., HouhouFidouh N., Reusken C.B.E.M., Bosch B.J., Drosten C., Koopmans M.P.G., Haagmans B.L. Severe acute respiratory syndrome coronavirus 2-specific antibody responses in coronavirus disease patients. Emerg Infect Dis 2020; 26(7): 1478-1488, https://doi.org/10.3201/eid2607.200841.

84. Marklund E., Leach S., Axelsson H., Nyström K., Norder H., Bemark M., Angeletti D., Lundgren A., Nilsson S., Andersson L.M., Yilmaz A., Lindh M., Liljeqvist J.Å., Gisslén M. Serum-IgG responses to SARS-CoV-2 after mild and severe COVID-19 infection and analysis of IgG non-responders. PLOS One 2020; 15(10): e0241104, https://doi.org/10.1371/journal. pone. 0241104 .

85. Pinto D., Park Y.J., Beltramello M., Walls A.C., Tortorici M.A., Bianchi S., Jaconi S., Culap K., Zatta F., De Marco A., Peter A., Guarino B., Spreafico R., Cameroni E., Case J.B., Chen R.E., Havenar-Daughton C., Snell G., Telenti A., Virgin H.W., Lanzavecchia A., Diamond M.S., Fink K., Veesler D., Corti D. Cross-neutralization of SARS-CoV-2 by a human monoclonal SARS-CoV antibody. Nature 2020; 583(7815): 290 295, https://doi.org/10.1038/s41586-020-2349-y.

86. Long Q.X., Tang X.J., Shi Q.L., Li Q., Deng H.J., Yuan J., Hu J.L., Xu W., Zhang Y., Lv F.J., Su K., Zhang F., Gong J., Wu B., Liu X.M., Li J.J., Qiu J.F., Chen J., Huang A.L. Clinical and immunological assessment of asymptomatic SARS-CoV-2 infections. Nat Med 2020; 26(8): 1200-1204, https://doi.org/10.1038/s41591-020-0965-6.

87. Wajnberg A., Amanat A., Firpo A., Altman D.R., Bailey M.J., Mansour M., McMahon M., Meade P., Mendu D.R., Muellers K., Stadlbauer D., Stone K., Strohmeier S., Aberg J., Reich D.L., Krammer F., Cordon-Cardo C. SARS-CoV-2 infection induces robust, neutralizing antibody responses that are stable for at least three months. medRxiv 2020, https://doi. org/10.1101/2020.07.14.20151126.

88. Xiao A.T., Gao C., Zhang S. Profile of specific antibodies to SARS-CoV-2: the first report. J Infect 2020; 81(1): 147-178, https://doi.org/10.1016/j.jinf.2020.03.012.

89. Cervia C., Nilsson J., Zurbuchen Y., Valaperti A., Schreiner J., Wolfensberger A., Raeber M.E., Adamo S., Weigang S., Emmenegger M., Hasler S., Bosshard P.P.,
De Cecco E., Bächli E., Rudiger A., Stüssi-Helbling M., Huber L.C., Zinkernagel A.S., Schaer D.J., Aguzzi A., Kochs G., Held U., Probst-Müller E., Rampini S.K., Boyman O. Systemic and mucosal antibody secretion specific to SARS-CoV-2 during mild versus severe COVID-19. J Allergy Clin Immunol 2021; 147(2): 545-557.e9, https://doi.org/10.1016/j.jaci.2020.10.040.

90. Zhao J., Yuan Q., Wang H., Liu W., Liao X., Su Y., Wang X., Yuan J., Li T., Li J., Qian S., Hong C., Wang F., Liu Y., Wang Z., He Q., Li Z., He B., Zhang T., Fu Y., Ge S., Liu L., Zhang J., Xia N., Zhang Z. Antibody responses to SARS-CoV-2 in patients with novel coronavirus disease 2019. Clin Infect Dis 2020; 71(16): 2027-2034, https://doi.org/10.1093/cid/ciaa344.

91. Zeng F., Dai C., Cai P., Wang J., Xu L., Li J., Hu G., Wang Z., Zheng F., Wang L. A comparison study of SARSCoV-2 IgG antibody between male and female COVID-19 patients: a possible reason underlying different outcome between sex. J Med Virol 2020; 92(10): 2050-2054, https://doi. org/10.1002/jmv.25989.

92. Davoudi-Monfared E., Rahmani H., Khalili $H$., Hajiabdolbaghi M., Salehi M., Abbasian L., Kazemzadeh H., Yekaninejad M.S. A randomized clinical trial of the efficacy and safety of interferon beta-1a in treatment of severe COVID-19. Antimicrob Agents Chemother 2020; 64(9): e01061-20, https:// doi.org/10.1128/aac.01061-20.

93. Zhou Q., Chen V., Shannon C.P., Wei X.S., Xiang X., Wang X., Wang Z.H., Tebbutt S.J., Kollmann T.R., Fish E.N. Interferon-alpha2b treatment for COVID-19. Front Immunol 2020; 11: 1061, https://doi.org/10.3389/fimmu.2020.01061.

94. Major J., Crotta S., Llorian M., McCabe T.M., Gad H.H., Priestnall S.L., Hartmann R., Wack A. Type I and III interferons disrupt lung epithelial repair during recovery from viral infection. Science 2020; 369(6504): 712-717, https://doi.org/10.1126/ science.abc2061.

95. Lazear H.M., Schoggins J.W., Diamond M.S. Shared and distinct functions of type I and type III interferons. Immunity 2019; 50(4): 907-923, https://doi.org/10.1016/j.immuni.2019.03.025.

96. Galani I.E., Triantafyllia V., Eleminiadou E.E., Koltsida O., Stavropoulos A., Manioudaki M., Thanos D., Doyle S.E., Kotenko S.V., Thanopoulou K., Andreakos E. Interferon- $\lambda$ mediates non-redundant front-line antiviral protection against influenza virus infection without compromising host fitness. Immunity 2017; 46(5): 875-890.e6, https://doi.org/10.1016/j. immuni.2017.04.025.

97. de Groen R.A., Boltjes A., Hou J., Liu B.S., McPhee F., Friborg J., Janssen H.L.A., Boonstra A. IFN- $\lambda$-mediated IL-12 production in macrophages induces IFN-y production in human NK cells. Eur J Immunol 2015; 45(1): 250-259, https://doi. org/10.1002/eji.201444903.

98. Broggi A., Ghosh S., Sposito B., Spreafico R., Balzarini F., Lo Cascio A., Clementi N., De Santis M., Mancini N., Granucci F., Zanoni I. Type III interferons disrupt the lung epithelial barrier upon viral recognition. Science 2020; 369(6504): 706-712, https://doi.org/10.1126/science.abc3545.

99. Market M., Angka L., Martel A.B., Bastin D., Olanubi O., Tennakoon G., Boucher D.M., Ng J., Ardolino M., Auer R.C. Flattening the COVID-19 curve with natural killer cell based immunotherapies. Front Immunol 2020; 11: 1512, https://doi. org/10.3389/fimmu.2020.01512.

100. Cao Z., Liu L., Du L., Zhang C., Jiang S., Li T., He Y. Potent and persistent antibody responses against the receptorbinding domain of SARS-CoV spike protein in recovered patients. Virol J 2010; 7: 299, https://doi.org/10.1186/1743$422 x-7-299$. 
101. Zhu Z., Chakraborti S., He Y., Roberts A., Sheahan T., Xiao X., Hensley L.E., Prabakaran P., Rockx B., Sidorov I.A., Corti D., Vogel L., Feng Y., Kim J.Q., Wang L.F., Baric R., Lanzavecchia A., Curtis K.M., Nabel G.J., Subbarao K., Jiang S., Dimitrov D.S. Potent cross-reactive neutralization of SARS coronavirus isolates by human monoclonal antibodies. Proc Natl Acad Sci U S A 2007; 104(29): 12123-12128, https:// doi.org/10.1073/pnas.0701000104.

102. Ying T., Li H., Lu L., Dimitrov D.S., Jiang $S$. Development of human neutralizing monoclonal antibodies for prevention and therapy of MERS-CoV infections. Microbes Infect 2015; 17(2): 142-148, https://doi.org/10.1016/j.micinf. 2014.11.008.

103. Chen X., Li R., Pan Z., Qian C., Yang Y., You R., Zhao J., Liu P., Gao L., Li Z., Huang Q., Xu L., Tang J., Tian Q., Yao W., Hu L., Yan X., Zhou X., Wu Y., Deng K., Zhang Z., Qian Z., Chen Y., Ye L. Human monoclonal antibodies block the binding of SARS-CoV-2 spike protein to angiotensin converting enzyme 2 receptor. Cell Mol Immunol 2020; 17(6): 647-649, https://doi.org/10.1038/s41423-020-0426-7.

104. Weinreich D.M., Sivapalasingam S., Norton T., Ali S., Gao H., Bhore R., Musser B.J., Soo Y., Rofail D., Im J., Perry C., Pan C., Hosain R., Mahmood A., Davis J.D., Turner K.C., Hooper A.T., Hamilton J.D., Baum A., Kyratsous C.A., Kim Y., Cook A., Kampman W., Kohli A., Sachdeva Y., Graber X., Kowal B., DiCioccio T., Stahl N., Lipsich L., Braunstein N., Herman G., Yancopoulos G.D.; Trial Investigators. REGN-COV2, a neutralizing antibody cocktail, in outpatients with COVID-19. N Engl J Med 2020; 384(3): 238251, https://doi.org/10.1056/nejmoa2035002.

105. Marano G., Vaglio S., Pupella S., Facco G., Catalano L., Liumbruno G.M., Grazzini G. Convalescent plasma: new evidence for an old therapeutic tool? Blood Transfus 2016; 14(2): 152-157, https://doi.org/10.2450/2015.0131-15.

106. Devasenapathy N., Ye Z., Loeb M., Fang F., Najafabadi B.T., Xiao Y., Couban R., Bégin P., Guyatt G. Efficacy and safety of convalescent plasma for severe COVID-19 based on evidence in other severe respiratory viral infections: a systematic review and meta-analysis. CMAJ 2020; 192(27): E745-E755, https://doi.org/10.1503/cmaj.200642.

107. Piechotta V., Chai K.L., Valk S.J., Doree C., Monsef I., Wood E.M., Lamikanra A., Kimber C., McQuilten Z., So-Osman C., Estcourt L.J., Skoetz N. Convalescent plasma or hyperimmune immunoglobulin for people with COVID-19: a living systematic review. Cochrane Database Syst Rev 2020; 7(7): CD013600, https://doi.org/10.1002/14651858.cd013600. pub2.

108. Shen C., Wang Z., Zhao F., Yang Y., Li J., Yuan J., Wang F., Li D., Yang M., Xing L., Wei J., Xiao H., Yang Y., Qu J., Qing L., Chen L., Xu Z., Peng L., Li Y., Zheng H., Chen F., Huang K., Jiang Y., Liu D., Zhang Z., Liu Y., Liu L. Treatment of 5 critically ill patients with COVID-19 with convalescent plasma. JAMA 2020; 323(16): 1582-1589, https://doi.org/10.1001/jama.2020.4783.

109. Duan K., Liu B., Li C., Zhang H., Yu T., Qu J., Zhou M., Chen L., Meng S., Hu Y., Peng C., Yuan M., Huang J., Wang Z., Yu J., Gao X., Wang D., Yu X., Li L., Zhang J., Wu X., Li B., Xu Y., Chen W., Peng Y., Hu Y., Lin L., Liu X., Huang S., Zhou Z., Zhang L., Wang Y., Zhang Z., Deng K., Xia Z., Gong Q., Zhang W., Zheng X., Liu Y., Yang H., Zhou D., Yu D., Hou J., Shi Z., Chen S., Chen Z., Zhang X., Yang X. Effectiveness of convalescent plasma therapy in severe COVID-19 patients. Proc Natl Acad
Sci U S A 2020; 117(7): 9490-9496, https://doi.org/10.1073/ pnas.2004168117.

110. Zhang B., Liu S., Tan T., Huang W., Dong Y., Chen L., Chen Q., Zhang L., Zhong Q., Zhang X., Zou Y., Zhang S. Treatment with convalescent plasma for critically ill patients with severe acute respiratory syndrome coronavirus 2 infection. Chest 2020; 158(1): e9-e13, https://doi.org/10.1016/j.chest. 2020.03.039.

111. Cheng Y., Wong R., Soo Y.O.Y., Wong W.S., Lee C.K., Ng M.H.L., Chan P., Wong K.C., Leung C.B., Cheng G. Use of convalescent plasma therapy in SARS patients in Hong Kong. Eur J Clin Microbiol Infect Dis 2005; 24(1): 44-46, https://doi.org/10.1007/s10096-004-1271-9.

112. Luke T.C., Kilbane E.M., Jackson J.L., Hoffman S.L. Meta-analysis: convalescent blood products for Spanish influenza pneumonia: a future H5N1 treatment? Ann Intern Med 2006; 145(8): 599-609, https://doi.org/10.7326/00034819-145-8-200610170-00139.

113. Chen L., Xiong J., Bao L., Shi Y. Convalescent plasma as a potential therapy for COVID-19. Lancet Infect Dis 2020; 20(4): 398-340, https://doi.org/10.1016/s1473-3099 (20)30141-9.

114. Mair-Jenkins J., Saavedra-Campos M., Baillie J.K., Cleary P., Khaw F.M., Lim W.S., Makki S., Rooney K.D., Nguyen-Van-Tam J.S., Beck C.R.; Convalescent Plasma Study Group. The effectiveness of convalescent plasma and hyperimmune immunoglobulin for the treatment of severe acute respiratory infections of viral etiology: a systematic review and exploratory meta-analysis. J Infect Dis 2015; 211(1): 80-90, https://doi.org/10.1093/infdis/jiu396.

115. Joyner M.J., Carter R.E., Senefeld J.W., Klassen S.A., Mills J.R., Johnson P.W., Theel E.S., Wiggins C.C., Bruno K.A., Klompas A.M., Lesser E.R., Kunze K.L., Sexton M.A., Diaz Soto J.C., Baker S.E., Shepherd J.R.A., van Helmond N., Verdun N.C., Marks P., van Buskirk C.M., Winters J.L., Stubbs J.R., Rea R.F., Hodge D.O., Herasevich V., Whelan E.R., Clayburn A.J., Larson K.F., Ripoll J.G., Andersen K.J., Buras M.R., Vogt M.N.P., Dennis J.J., Regimbal R.J., Bauer P.R., Blair J.E., Paneth N.S., Fairweather D.L., Wright R.S., Casadevall A. Convalescent plasma antibody levels and the risk of death from COVID-19. New Eng J Med 2021; 384(11): 1015-1027, https://doi.org/10.1056/nejmoa2031893.

116. Ahn J.Y., Sohn Y., Lee S.H., Cho Y., Hyun J.H., Baek Y.J., Jeong S.J., Kim J.H., Ku N.S., Yeom J.S., Roh J., Ahn M.Y., Chin B.S., Kim Y.S., Lee H., Yong D., Kim H.O., Kim S., Choi J.Y. Use of convalescent plasma therapy in two COVID-19 patients with acute respiratory distress syndrome in Korea. J Korean Med Sci 2020; 35(14): e149, https://doi. org/10.3346/jkms.2020.35.e149.

117. Pei S., Yuan X., Zhang Z., Yao R., Xie Y., Shen M., Li B., Chen X., Yin M. Convalescent plasma to treat COVID-19: Chinese strategy and experiences. medRxiv 2020, https://doi. org/10.1101/2020.04.07.20056440.

118. Tanne J.H. COVID-19: FDA approves use of convalescent plasma to treat critically ill patients. BMJ 2020; 368: m1256, https://doi.org/10.1136/bmj.m1256.

119. Brown B.L., McCullough J. Treatment for emerging viruses: convalescent plasma and COVID-19. Transfus Apher Sci 2020; 59(3): 102790, https://doi.org/10.1016/j. transci.2020.102790.

120. Jamilloux Y., Henry T., Belot A., Viel S., Fauter M., Jammal T.E., Walzer T., François B., Sèvea P. Should we 
stimulate or suppress immune responses in COVID-19? Cytokine and anti-cytokine interventions. Autoimmun Rev 2020; 19(7): 102567, https://doi.org/10.1016/j.autrev.2020.102567.

121. Guan W.J., Ni Z.Y., Hu Y., Liang W.H., Ou C.Q., He J.X., Liu L., Shan H., Le C.L., Hui D.S.C., Du B., Li L.J., Zeng G., Yuen K.Y., Chen R.C., Tang C.L., Wang T., Chen P.Y., Xiang J., Li S.Y., Wang J.L., Liang Z.J., Peng Y.X., Wei L., Liu Y., Hu Y.H., Peng P., Wang J.M., Liu J.Y., Chen Z., Li G., Zheng Z.J., Qiu S.Q., Luo J., Ye C.J., Zhu S.Y., Zhong N.S. Clinical characteristics of coronavirus disease 2019 in China. New Engl J Med 2020; 382(18): 1708-1720, https://doi. org/10.1056/nejmoa2002032.

122. Polak S.B., Van Gool I.C., Cohen D., von der Thüsen J.H., van Paassen J. A systematic review of pathological findings in COVID-19: a pathophysiological timeline and possible mechanisms of disease progression. Mod Pathol 2020; 33(11): 2128-2138, https://doi.org/10.1038/ s41379-020-0603-3.

123. Villar J., Ferrando C., Martínez D., Ambrós A., Muñoz T., Soler J.A., Aguilar G., Alba F., González-Higueras E., Conesa L.A., Martín-Rodríguez C., Díaz-Domínguez F.J., Serna-Grande P., Rivas R., Ferreres J., Belda J., Capilla L., Tallet A., Añón J.M., Fernández R.L., González-Martín J.M. Dexamethasone treatment for the acute respiratory distress syndrome: a multicentre, randomised controlled trial. Lancet Respir Med 2020; 8(3): 267-276, https://doi.org/10.1016/ s2213-2600(19)30417-5.

124. Villar J., Confalonieri M., Pastores S.M., Meduri G.U. Rationale for prolonged corticosteroid treatment in the acute respiratory distress syndrome caused by coronavirus disease 2019. Crit Care Explor 2020; 2(4): e0111, https://doi. org/10.1097/cce.0000000000000111.

125. Alijotas-Reig J., Esteve-Valverde E., Belizna C., Selva-O'Callaghan A., Pardos-Gea J., Quintana A., Mekinian A., Anunciacion-Llunell A., Miró-Mur F. Immunomodulatory therapy for the management of severe COVID-19. Beyond the anti-viral therapy: a comprehensive review. Autoimmun Rev 2020; 19(7): 102569, https://doi. org/10.1016/j.autrev.2020.102569.

126. Jiang S., Liu T., Hu Y., Li R., Di X., Jin X., Wang Y., Wang K. Efficacy and safety of glucocorticoids in the treatment of severe community-acquired pneumonia: a meta-analysis. Medicine (Baltimore) 2019; 98(26): e16239, https://doi. org/10.1097/md.0000000000016239.

127. Li H., Chen C., Hu F., Wang J., Zhao Q., Gale R.P., Liang Y. Impact of corticosteroid therapy on outcomes of persons with SARS-CoV-2, SARS-CoV, or MERS-CoV infection: a systematic review and meta-analysis. Leukemia 2020; 34(6): 1503-1511, https://doi.org/10.1038/s41375-020-0848-3.

128. Singh A.K., Majumdar S., Singh R., Misra A. Role of corticosteroid in the management of COVID-19: a systemic review and a clinician's perspective. Diabetes Metab Syndr 2020; 14(5): 971-978, https://doi.org/10.1016/j.dsx.2020.06.054.

129. Veronese N., Demurtas J., Yang L., Tonelli.R., Barbagallo M., Lopalco P., Lagolio E., Celotto S., Pizzol D., Zou L., Tully M.A., Ilie P.C., Trott M., López-Sánchez G.F., Smith L. Use of corticosteroids in coronavirus disease 2019 pneumonia: a systematic review of the literature. Front Med (Lausanne) 2020; 7: 170, https://doi.org/10.3389/fmed. 2020.00170.

130. Arabi Y.M., Mandourah Y., Al-Hameed F., Sindi A.A., Almekhlafi G.A., Hussein M.A., Jose J., Pinto R., Al-Omari A., Kharaba A., Almotairi A., Al Khatib K.,
Alraddadi B., Shalhoub S., Abdulmomen A., Qushmaq I., Mady A., Solaiman O., Al-Aithan A.M., Al-Raddadi R., Ragab A., Balkhy H.H., Al Harthy A., Deeb A.M., Al Mutairi H., Al-Dawood A., Merson L., Hayden F.G., Fowler R.A. Corticosteroid therapy for critically ill patients with Middle East Respiratory Syndrome. Am J Respir Crit Care Med 2018; 197(6): 757-767, https://doi.org/10.1164/rccm.201706-1172oc.

131. Russell C.D., Millar J.E., Baillie J.K. Clinical evidence does not support corticosteroid treatment for 2019-nCoV lung injury. Lancet 2020; 395(10223): 473-475, https://doi. org/10.1016/S0140-6736(20)30317-2.

132. Stockman L.J., Bellamy R., Garner P. SARS: systematic review of treatment effects. PLoS Med 2006; 3(9): e343, https://doi.org/10.1371/journal.pmed.0030343.

133. RECOVERY Collaborative Group; Horby P., Lim W.S., Emberson J.R., Mafham M., Bell J.L., Linsell L., Staplin N., Brightling C., Ustianowski A., Elmahi E., Prudon B., Green C., Felton T., Chadwick D., Rege K., Fegan C., Chappell L.C., Faust S.N., Jaki T., Jeffery K., Montgomery A., Rowan K., Juszczak E., Baillie J.K., Haynes R., Landray M.J. Dexamethasone in hospitalized patients with COVID-19. N Engl J Med 2021; 384(8): 693-704, https://doi.org/10.1056/ nejmoa2021436.

134. WHO Rapid Evidence Appraisal for COVID-19 Therapies (REACT) Working Group; Sterne J.A.C., Murthy S., Diaz J.V., Slutsky A.S., Villar J., Angus D.C., Annane D., Azevedo L.C.P., Berwanger O., Cavalcanti A.B., Dequin P.F., Du B., Emberson J., Fisher D., Giraudeau B., Gordon A.C., Granholm A., Green C., Haynes R., Heming N., Higgins J.P.T., Horby P., Jüni P., Landray M.J., Le Gouge A., Leclerc M., Lim W.S., Machado F.R., McArthur C., Meziani F., Møller M.H., Perner A., Petersen M.W., Savovic J., Tomazini B., Veiga V.C., Webb S., Marshall J.C. Association between administration of systemic corticosteroids and mortality among critically III patients with COVID-19: a meta-analysis. JAMA 2020; 324(13): 1330-1341, https://doi.org/10.1001/jama.2020.17023.

135. World Health Organization. COVID-19 Clinical management: living guidance. URL: https://www.who.int/ publications/i/item/clinical-management-of-covid-19.

136. Alhazzani W., Møller M.H., Arabi Y.M., Loeb M., Gong M.N., Fan E., Oczkowski S., Levy M.M., Derde L., Dzierba A., Du B., Aboodi M., Wunsch H., Cecconi M., Koh Y., Chertow D.S., Maitland K., Alshamsi F., Belley-Cote E., Greco M., Laundy M., Morgan J.S., Kesecioglu J., McGeer A., Mermel L., Mammen M.J., Alexander P.E., Arrington A., Centofanti J.E., Citerio G., Baw B., Memish Z.A., Hammond N., Hayden F.G., Evans L., Rhodes A. Surviving Sepsis Campaign: guidelines on the management of critically ill adults with coronavirus disease 2019 (COVID-19). Intensive Care Med 2020; 46(5): 854-887, https://doi.org/10.1007/s00134-020-06022-5.

137. van Paassen J., Vos J.S., Hoekstra E.M., Neumann K.M.I., Boot P.C., Arbous S.M. Corticosteroid use in COVID-19 patients: a systematic review and meta-analysis on clinical outcomes. Crit Care 2020; 24(1): 696, https://doi. org/10.1186/s13054-020-03400-9.

138. Siddiqi H.K., Mehra M.R. COVID-19 illness in native and immunosuppressed states: a clinical-therapeutic staging proposal. J Heart Lung Transplant 2020; 39(5): 405-407, https://doi.org/10.1016/j.healun.2020.03.012.

139. Chen Y., Feng Z., Diao B., Wang R., Wang G., Wang C., Tan Y., Liu L., Wang C., Liu Y., Yuan Z., Ren L., Wu Y., Chen $Y$. The novel severe acute respiratory syndrome coronavirus 2 (SARS-CoV-2) directly decimates human 
spleens and lymph nodes. medRxiv 2020, https://doi.org/10. 1101/2020.03.27.20045427.

140. Gong J., Dong H., Xia S.Q., Huang Y.Z., Wang D.K., Zhao Y., Liu W.H., Tu S.H., Zhang M.M., Wang Q., Lu F.E. Correlation analysis between disease severity and inflammation-related parameters in patients with COVID-19 pneumonia. BMC Infect Dis 2020; 20(1): 963, https://doi. org/10.1186/s12879-020-05681-5.

141. Moore J.B., June C.H. Cytokine release syndrome in severe COVID-19. Science 2020; 368(6490): 473-474, https:// doi.org/10.1126/science.abb8925.

142. Coomes E.A., Haghbayan H. Interleukin-6 in COVID-19: a systematic review and meta-analysis. Rev Med Virol 2020; 30(6): 1-9, https://doi.org/10.1101/2020.03.30.200 48058 .

143. Perrone F., Piccirillo M.C., Ascierto P.A., Salvarani C., Parrella R., Marata A.M., Popoli P., Ferraris L., MarroccoTrischitta M.M., Ripamonti D., Binda F., Bonfanti P., Squillace N., Castelli F., Muiesan M.L., Lichtner M., Calzetti C., Salerno N.D., Atripaldi L., Cascella M., Costantini M., Dolci G., Facciolongo N.C., Fraganza F., Massari M., Montesarchio V., Mussini C., Negri E.A., Botti G., Cardone C., Gargiulo P., Gravina A., Schettino C., Arenare L., Chiodini P., Gallo C.; TOCIVID-19 investigators, Italy. Tocilizumab for patients with COVID-19 pneumonia. The single-arm TOCIVID-19 prospective trial. J Trans/ Med 2020; 18(1): 405, https://doi. org/10.1186/s12967-020-02573-9.

144. Xu X., Han M., Li T., Sun W., Wang D., Fu B., Zhou Y., Zheng X., Yang Y., Li X., Zhang X., Pan A., Wei H. Effective treatment of severe COVID-19 patients with tocilizumab. Proc Natl Acad Sci U S A 2020; 117(20): 10970-10975, https://doi. org/10.1073/pnas.2005615117.

145. Roumier M., Paule R., Groh M., Vallée A., Ackermann F. Interleukin-6 blockade for severe COVID-19. medRxiv 2020, https://doi.org/10.1101/2020.04.20.20061861.

146. Sanofi and Regeneron provide update on U.S. Phase 2/3 adaptive-designed trial in hospitalized COVID-19 patients. URL: https://www.sanofi.com/en/media-room/press-releases/ 2020/2020-04-27-12-58-00.

147. Vremennye metodicheskie rekomendatsii. Profilaktika, diagnostika $i$ lechenie novoy koronavirusnoy infektsil (COVID-19). Versiya 9 (26.10.2020) [Temporary guidelines. Prevention, diagnosis and treatment of new coronavirus infection (COVID-19) Version 9. (10/26/2020)]. URL: https:// static-0.minzdrav.gov.ru/system/attachments/attaches/ 000/052/548/original/MP_COVID-19_\%28v.9\%29.pdf.

148. Wicks I.P., Roberts A.W. Targeting GM-CSF in inflammatory diseases. Nat Rev Rheumatol 2016; 12(1): 3748, https://doi.org/10.1038/nrrheum.2015.161.

149. Guo X., Higgs B.W., Bay-Jensen A.C., Wu Y., Karsdal M.A., Kuziora M., Godwood A., Close D., Ryan P.C., Roskos L.K., White W.I. Blockade of GM-CSF pathway induced sustained suppression of myeloid and $T$ cell activities in rheumatoid arthritis. Rheumatology (Oxford) 2018; 57(1): 175-184, https://doi.org/10.1093/rheumatology/kex383.

150. Spinelli F.R., Conti F., Gadina M. HiJAKing SARSCoV-2? The potential role of JAK inhibitors in the management of COVID-19. Sci Immunol 2020; 5(47), https://doi.org/10.1126/ sciimmunol.abc5367.

151. Tanaka Y., Mclnnes I.B., Taylor P.C., Byers N.L., Chen L., de Bono S., Issa M., Macias W.L., Rogai V., Rooney T.P., Schlichting D.E., Zuckerman S.H., Emery P. Characterization and changes of lymphocyte subsets in baricitinib-treated patients with rheumatoid arthritis: an integrated analysis. Arthritis Rheumatol 2018; 70(12): 19231932, https://doi.org/10.1002/art.40680.

152. Chen I.Y., Moriyama M., Chang M.F., Ichinohe T. Severe acute respiratory syndrome coronavirus viroporin $3 a$ activates the NLRP3 inflammasome. Front Microbiol 2019; 10: 50, https://doi.org/10.3389/fmicb.2019.00050.

153. Nieto-Torres J.L., Verdiá-Báguena C., JimenezGuardeño J.M., Regla-Nava J.A., Castaño-Rodriguez C., Fernandez-Delgado R., Torres J., Aguilella V.M., Enjuanes L. Severe acute respiratory syndrome coronavirus $\mathrm{E}$ protein transports calcium ions and activates the NLRP3 in ammasome. Virology 2015; 485: 330-339, https://doi. org/10.1016/j.virol.2015.08.010.

154. Conti P., Gallenga C.E., Tetè G., Cara A., Ronconi G., Younes A., Toniato E., Ross R., Kritas S.K. How to reduce the likelihood of coronavirus-19 (CoV-19 or SARS- CoV-2) infection and lung inflammation mediated by IL-1. J Biol Regul Homeost Agents 2020; 34(2): 333-338, https://doi.org/10.23812/ editorial-conti-2.

155. Tardif J.C., Kouz S., Waters D.D., Bertrand O.F., Diaz R., Maggioni A.P., Pinto F.J., Ibrahim R., Gamra H., Kiwan G.S., Berry C., López-Sendón J., Ostadal P., Koenig W., Angoulvant D., Grégoire J.C., Lavoie M.A., Dubé M.P., Rhainds D., Provencher M., Blondeau L., Orfanos A., L'Allier P.L., Guertin M.C., Roubille F. Efficacy and safety of lowdose colchicine after myocardial infarction. N Engl J Med 2019; 381(26): 2497-2505, https://doi.org/10.1056/nejmoa1912388.

156. Deftereos S.G., Giannopoulos G., Vrachatis D.A., Siasos G.D., Giotaki S.G., Gargalianos P., Metallidis S., Sianos G., Baltagiannis S., Panagopoulos P., Dolianitis K., Randou E., Syrigos K., Kotanidou A., Koulouris N.G., Milionis H., Sipsas N., Gogos C., Tsoukalas G., Olympios C.D., Tsagalou E., Migdalis I., Gerakari S., Angelidis C., Alexopoulos D., Davlouros P., Hahalis G., Kanonidis I., Katritsis D., Kolettis T., Manolis A.S., Michalis L., Naka K.K., Pyrgakis V.N., Toutouzas K.P., Triposkiadis F., Tsioufis K., Vavouranakis E., Martinèz-Dolz L., Reimers B., Stefanini G.G., Cleman M., Goudevenos J., Tsiodras S., Tousoulis D., lliodromitis E., Mehran R., Dangas G., Stefanadis C.; GRECCO-19 investigators. Effect of colchicine vs standard care on cardiac and inflammatory biomarkers and clinical outcomes in patients hospitalized with coronavirus disease 2019: the GRECCO-19 randomized clinical trial. JAMA Netw Open 2020; 3(6): e2013136, https://doi.org/10.1001/ jamanetworkopen.2020.13136.

157. Lu Y., Chen J., Xiao M., Li W., Miller D.D. An overview of tubulin inhibitors that interact with the colchicine binding site. Pharm Res 2012; 29(11): 2943-2971, https://doi.org/10.1007/ s11095-012-0828-z.

158. Montreal Heart Institute. Colchicine coronavirus SARS-CoV2 trial (COLCORONA) (COVID-19). URL: https:// clinicaltrials.gov/ct2/show/nct04322682.

159. Shubnikova E.V., Bukatina T.M., Velts N.Yu., Kaperko D.A., Kutekhova G.V. Immune response checkpoint inhibitors: new risks of a new class of antitumor agents. Bezopasnost' i risk farmakoterapii 2020; 8(1): 9-22, https://doi. org/10.30895/2312-7821-2020-8-1-9-22.

160. Hamashima R., Uchino J., Morimoto Y., Iwasaku M., Kaneko Y., Yamada T., Takayama K. Association of immune checkpoint inhibitors with respiratory infections: a review. Cancer Treat Rev 2020; 90: 102109, https://doi.org/10.1016/j. ctrv.2020.102109. 
161. Kattan J., Kattan C., Assi T. Do checkpoint inhibitors compromise the cancer patients' immunity and increase the vulnerability to COVID-19 infection? Immunotherapy 2020; 12(6): 351-354, https://doi.org/10.2217/imt-2020-0077.

162. Gatto L., Franceschi E., Nunno V.D., Brandes A.A. Potential protective and therapeutic role of immune checkpoint inhibitors against viral infections and COVID-19. Immunotherapy 2020; 12(15): 1111-1114, https://doi.org/10. 2217/imt-2020-0109.

163. Lukomska B., Stanaszek L., Zuba-Surma E., Legosz P., Sarzynska S., Drela K. Challenges and controversies in human mesenchymal stem cell therapy. Stem Cells Int 2019; 9628536, https://doi.org/10.1155/2019/9628536.

164. Shetty A.K. Mesenchymal stem cell infusion shows promise for combating coronavirus (COVID-19)-induced pneumonia. Aging Dis 2020; 11(2): 462-464, https://doi. org/10.14336/ad.2020.0301.

165. Leng Z., Zhu R., Hou W., Feng Y., Yang Y., Han Q., Shan G., Meng F., Du D., Wang S., Fan J., Wang W., Deng L., Shi H., Li H., Hu Z., Zhang F., Gao J., Liu H., Li X., Zhao Y., Yin K., He X., Gao Z., Wang Y., Yang B., Jin R., Stambler I., Lim L.W., Su H., Moskalev A., Cano A., Chakrabarti S., Min K.J., Ellison-Hughes G., Caruso C., Jin K., Zhao R.C. Transplantation of ACE2(-) mesenchymal stem cells improves the outcome of patients with COVID-19 pneumonia. Aging Dis 2020; 11(2): 216-228, https://doi.org/10.14336/ad.2020.0228.

166. Shu L., Niu C., Li R., Huang T., Wang Y., Huang M., Ji N., Zheng Y., Chen X., Shi L., Wu M., Deng K., Wei J., Wang X., Cao Y., Yan J., Feng G. Treatment of severe COVID-19 with human umbilical cord mesenchymal stem cells. Stem Cell Res Ther 2020; 11(1): 36, https://doi.org/10.1186/ s13287-020-01875-5.

167. Tufan A., Avanoğlu Güler A., Matucci-Cerinic M. COVID-19, immune system response, hyperinflammation and repurposing antirheumatic drugs. Turk J Med Sci 2020; 50(SI-1): 620-632, https://doi.org/10.3906/sag-2004-168.

168. Tregoning J.S., Brown E.S., Cheeseman H.M., Flight K.E., Higham S.L., Lemm N.M., Pierce B.F., Stirling D.C., Wang Z., Pollock K.M. Vaccines for COVID-19. Clin Exp Immunol 2020; 202(2): 162-192, https://doi.org/10.1111/ cei.13517.

169. Fu Y., Cheng Y., Wu Y. Understanding SARS-CoV2-mediated inflammatory responses: from mechanisms to potential therapeutic tools. Virol Sin 2020; 35(3): 266-271, https://doi.org/10.1007/s12250-020-00207-4.

170. Tseng C.T., Sbrana E., Iwata-Yoshikawa N., Newman P.C., Garron T., Atmar R.L., Peters C.J., Couch R.B. Immunization with SARS coronavirus vaccines leads to pulmonary immunopathology on challenge with the SARS virus. PLoS One 2012; 7(4): e35421, https://doi.org/10.1371/ journal.pone.0035421.

171. Liu L., Wei Q., Lin Q., Fang J., Wang H., Kwok H., Tang H., Nishiura K., Peng J., Tan Z., Wu T., Cheung K.W., Chan K.H., Alvarez X., Qin C., Lackner A., Perlman S., Yuen K.Y., Chen Z. Anti-spike IgG causes severe acute lung injury by skewing macrophage responses during acute SARSCoV infection. JCI Insight 2019; 4(4): e123158, https://doi. org/10.1172/jci.insight.123158.

172. Wan Y., Shang J., Sun S., Tai W., Chen J., Geng Q., He L., Chen Y., Wu J., Shi Z., Zhou Y., Du L., Li F. Molecular mechanism for antibody-dependent enhancement of coronavirus entry. J Virol 2020; 94(5): e02015-19, https://doi. org/10.1128/jvi.02015-19.
173. Rauh L.W., Schmidt R. Measles immunization with killed virus vaccine: serum antibody titers and experience with exposure to measles epidemic. $A m \mathrm{~J}$ Dis Child 1965; 109: 232-237, https://doi.org/10.1001/ archpedi.1965.02090020234007.

174. Kim H.W., Canchola J.G., Brandt C.D., Pyles G., Chanock R.M., Jensen K., Parrott R.H. Respiratory syncytial virus disease in infants despite prior administration of antigenic inactivated vaccine. Am J Epidemiol 1969; 89(4): 422-434, https://doi.org/10.1093/oxfordjournals.aje.a120955.

175. Sridhar S., Luedtke A., Langevin E., Zhu M., Bonaparte M., Machabert T., Savarino S., Zambrano B., Moureau A., Khromava A., Moodie Z., Westling T., Mascareñas C., Frago C., Cortés M., Chansinghaku D., Noriega F., Bouckenooghe A., Chen J., Ng S.P., Gilbert P.D., Gurunathan S., DiazGranados C.A. Effect of dengue serostatus on dengue vaccine safety and efficacy. $N$ Engl J Med 2018; 379(4): 327-340, https://doi.org/10.1056/ nejmoa1800820.

176. World Health Organization. Draft landscape and tracker of COVID-19 candidate vaccines. 2020. URL: https:// www.who.int/publications/m/item/draft-landscape-of-COVID19-candidate-vaccines.

177. World Health Organization. Status of COVID-19 Vaccines within WHO EUL/PQ evaluation process. URL: https://extranet.who.int/pqweb/sites/default/files/documents/ Status_COVID_VAX_18May2021.pdf.

178. Wang Q., Li C., Zhang Q., Wang T., Li J., Guan W., Yu J., Liang M., Li D. Interactions of SARS coronavirus nucleocapsid protein with the host cell proteasome subunit p42. Virol J 2010; 7: 99, https://doi.org/10.1186/1743422x-7-99.

179. Oliver S.E., Gargano J.W., Marin M., Wallace M., Curran K.G., Chamberland M., McClung N., CamposOutcalt D., Morgan R.L., Mbaeyi S., Romero J.R., Talbot H.K., Lee G.M., Bell B.P., Dooling K. The Advisory Committee on Immunization Practices' Interim Recommendation for Use of Pfizer-BioNTech COVID-19 Vaccine - United States, December 2020. MMWR Morb Mortal Wkly Rep 2020; 69: 1922-1924, https://doi.org/10.15585/mmwr.mm6950e2.

180. Laczkó D., Hogan M.J., Toulmin S.A., Hicks P., Lederer K., Gaudette B.T., Castaño D., Amanat F., Muramatsu H., Oguin T.H. III, Ojha A., Zhang L., Mu Z., Parks R., Manzoni T.B., Roper B., Strohmeier S., Tombácz I., Arwood L., Nachbagauer R., Karikó K., Greenhouse J., Pessaint L., Porto M., Putman-Taylor T., Strasbaugh A., Campbell T.A., Lin P.J.C., Tam Y.K., Sempowski G.D., Farzan M., Choe H., Saunders K.O., Haynes B.F., Andersen H., Eisenlohr L.C., Weissman D., Krammer F., Bates P., Allman D., Locci M., Pardi N. A single immunization with nucleoside-modified mRNA vaccines elicits strong cellular and humoral immune responses against SARS-CoV-2 in mice. Immunity 2020; 53(4): 724-732.e7, https://doi.org/10.1016/j. immuni.2020.07.019.

181. Mulligan M.J., Lyke K.E., Kitchin N., Absalon J., Gurtman A., Lockhart S., Neuzil K., Raabe V., Bailey R., Swanson K.A., Li P., Koury K., Kalina W., Cooper D., FontesGarfias C., Shi P.Y., Türeci Ö., Tompkins K.R., Walsh E.E., Frenck R., Ann R., Falsey A.R., Dormitzer P.R., Gruber W.C., Şahin U., Jansen K.U. Phase I/II study of COVID-19 RNA vaccine BNT162b1 in adults. Nature 2020; 586(7830): 589593, https://doi.org/10.1038/s41586-020-2639-4.

182. Polack F.P., Thomas S.J., Kitchin N., Absalon J., 
Gurtman A., Lockhart S., Perez J.L., Pérez Marc G., Moreira E.D., Zerbini C., Bailey R., Swanson K.A., Roychoudhury S., Koury K., Li P., Kalina W.V., Cooper D., Frenck R.W. Jr., Hammitt L.L., Türeci Ö., Nell H., Schaefer A., Ünal S., Tresnan D.B., Mather S., Dormitzer P.R., Şahin U., Jansen K.U., Gruber W.C.; C4591001 Clinical Trial Group. Safety and efficacy of the BNT162b2 mRNA COVID-19 vaccine. N Engl J Med 2020; 383(27): 2603-2615, https://doi. org/10.1056/nejmoa2034577.

183. Folegatti P.M., Ewer K.J., Aley P.K., Angus B., Becker S., Belij-Rammerstorfer S., Bellamy D., Bibi S., Bittaye M., Clutterbuck E.A., Dold C., Faust S.N., Finn A., Flaxman A.L., Hallis B., Heath P., Jenkin D., Lazarus R., Makinson R., Minassian A.M., Pollock K.M., Ramasamy M., Robinson H., Snape M., Tarrant R., Voysey M., Green C., Douglas A.D., Hill A.V.S., Lambe T., Gilbert S.C., Pollard A.J.; Oxford COVID Vaccine Trial Group. Safety and immunogenicity of the ChAdOx1 nCoV-19 vaccine against SARS-CoV-2: a preliminary report of a phase $1 / 2$, single-blind, randomised controlled trial. Lancet 2020; 396(10249): 467-478, https://doi. org/10.1016/s0140-6736(20)31604-4.

184. Sadoff J., Gray G., Vandebosch A., Cárdenas V., Shukarev G., Grinsztejn B., Goepfert P.A., Truyers C., Fennema H., Spiessens B., Offergeld K., Scheper G., Taylor K.L., Robb M.L., Treanor J., Barouch D.H., Stoddard J., Ryser M.F., Marovich M.A., Neuzil K.M., Corey L., Cauwenberghs N., Tanner T., Hardt K., Ruiz-Guiñazú J., Le Gars M., Schuitemaker H., Van Hoof J., Struyf F., Douoguih M.; ENSEMBLE Study Group. Safety and efficacy of single-dose Ad26.COV2.S vaccine against COVID-19. N Engl J Med 2021, https://doi.org/10.1056/nejmoa2101544.

185. Corbett K.S., Edwards D., Leist S.R., Abiona O.M., Boyoglu-Barnum S., Gillespie R.A., Himansu S., Schäfer A., Ziwawo C.T., DiPiazza A.T., Dinnon K.H., Elbashir S.M., Shaw C.A., Woods A., Fritch E.J., Martinez D.R., Bock K.W., Minai M., Nagata B.M., Hutchinson G.B., Bahl K., GarciaDominguez D., Ma L., Renzi I., Kong W.P., Schmidt S.D., Wang L., Zhang Y., Stevens L.J., Phung E., Chang L.A., Loomis R.J., Altaras N.E., Narayanan E., Metkar M., Presnyak V., Liu C., Louder M.K., Shi W., Leung K., Yang E.S., West A., Gully K.L., Wang N., Wrapp D., DoriaRose N.A., Stewart-Jones G., Bennett H., Nason M.C., Ruckwardt T.J., McLellan J.S., Denison M.R., Chappell J.D., Moore I.N., Morabito K.M., Mascola J.R., Baric R.S., Carfi A., Graham B.S. SARS-CoV-2 mRNA vaccine development enabled by prototype pathogen preparedness. bioRxiv 2020; 11: 2020.06.11.145920, https://doi. org/10.1101/2020.06.11.145920.

186. Jackson L.A., Anderson E.J., Rouphael N.G., Roberts P.C., Makhene M., Coler R.N., McCullough M.P., Chappell J.D., Denison M.R., Stevens L.J., Pruijssers A.J., McDermott A., Flach B., Doria-Rose N.A., Corbett K.S., Morabito K.M., O'Dell S., Schmidt S.D., Swanson P.A., Padilla M., Mascola J.R., Neuzil K.M., Bennett H., Sun W., Peters E., Makowski M., Albert J., Cross K., Buchanan W., Pikaart-Tautges R., Ledgerwood J.E., Graham B.S., Beigel J.H.; mRNA-1273 Study Group. An mRNA vaccine against SARS-CoV-2 - preliminary report. N Engl J Med 2020; 383(20): 1920-1931, https://doi.org/10.1056/nejmoa2022483.

187. Baden L.R., El Sahly H.M., Essink B., Kotloff K., Frey S., Novak R., Diemert D., Spector S.A., Rouphael N., Creech C.B., McGettigan J., Khetan S., Segall N., Solis J.,
Brosz A., Fierro C., Schwartz H., Neuzil K., Corey L., Gilbert P., Janes H., Follmann D., Marovich M., Mascola J., Polakowski L., Ledgerwood J., Graham B.S., Bennett H., Pajon R., Knightly C., Leav B., Deng W., Zhou H., Han S., Ivarsson M., Miller J., Zaks T.; COVE Study Group. Efficacy and safety of the mRNA1273 SARS-CoV-2 vaccine. N Engl J Med 2021; 384(5): 403416, https://doi.org/10.1056/nejmoa2035389.

188. WHO lists additional COVID-19 vaccine for emergency use and issues interim policy recommendations. URL: https:// www.who.int/news/item/07-05-2021-who-lists-additionalcovid-19-vaccine-for-emergency-use-and-issues-interimpolicy-recommendations.

189. Logunov D.Y., Dolzhikova I.V., Zubkova O.V., Tukhvatulin A.I., Shcheblyakov D.V., Dzharullaeva A.S., Grousova D.M., Erokhova A.S., Kovyrshina A.V., Botikov A.G., Izhaeva F.M., Popova O., Ozharovskaya T.A., Esmagambetov I.B., Favorskaya I.A., Zrelkin D.I., Voronina D.V., Shcherbinin D.N., Semikhin A.S., Simakova Y.V., Tokarskaya E.A., Lubenets N.L., Egorova D.A., Shmarov M.M., Nikitenko N.A., Morozova L.F., Smolyarchuk E.A., Kryukov E.V., Babira V.F., Borisevich S.V., Naroditsky B.S., Gintsburg A.L. Safety and immunogenicity of an rAd26 and rAd5 vector-based heterologous prime-boost COVID-19 vaccine in two formulations: two open, non-randomised phase 1/2 studies from Russia. Lancet 2020; 396(10255): 887-897, https://doi.org//10.1016/s0140-6736(20)31866-3.

190. Logunov D.Y., Dolzhikova I.V., Zubkova O.V., Tukhvatulin A.I., Shcheblyakov D.V., Dzharullaeva A.S., Kovyrshina A.V., Lubenets N.L., Grousova D.M., Erokhova A.S., Botikov A.G., Izhaeva F.M., Popova O., Ozharovskaya T.A., Esmagambetov I.B., Favorskaya I.A., Zrelkin D.I., Voronina D.V., Shcherbinin D.N., Semikhin A.S., Simakova Y.V., Tokarskaya E.A., Egorova D.A., Shmarov M.M., Nikitenko N.A., Smolyarchuk E.A., Gushchin V.A., Zyryanov S.K., Borisevich S.V., Naroditsky B.S., Gintsburg A.L.; Gam-COVID-Vac Vaccine Trial Group. Safety and efficacy of an rAd26 and rAd5 vector-based heterologous prime-boost COVID-19 vaccine: an interim analysis of a randomised controlled phase 3 trial in Russia. Lancet 2020; 397(10275): 671-681, https://doi. org/10.1016/s0140-6736(21)00234-8.

191. Ryzhikov A.B., Ryzhikov E.A., Bogryantseva M.P., Usova S.V., Danilenko E.D., Nechaeva E.A., Pyankov O.V., Pyankova O.G., Gudymo A.S., Bodnev S.A., Onkhonova G.S., Sleptsova E.S., Kuzubov V.I., Ryndyuk N.N., Ginko Z.I, Petrov V.N., Moiseeva A.A., Torzhkova P.Yu., Pyankov S.A., Tregubchak T.V., Antonec D.V., Gavrilova E.V. Maksyutov R.A. A single blind, placebo-controlled randomized study of the safety, reactogenicity and immunogenicity of the "EpiVacCorona" Vaccine for the prevention of COVID-19, in volunteers aged 1860 years (phase I-II). Infektsiya i immunitet 2021; 11 (2): 283296, https://doi.org/10.15789/2220-7619-ASB-1699.

192. URL: https://covivac.ru/.

193. Lyadova I.V, Starikov A.A. COVID-19 and BCG vaccine: is there a link? Infektsiya i immunitet 2020; 10(3): 459-468, https:/ldol.org/10.15789/2220-7619-cab-1472.

194. Sohrabi Y, Dos Santos J.C,, Dorenkamp M., Findeisen H., Godfrey R., Netea M.G., Joosten L.A. Trained immunity as a novel approach against COVID-19 with a focus on Bacillus Calmette-Guérin yaccine. mechanisms, challenges and perspectives. Clin Trans/ Immunology 2020; 9(12): e1228, https://doi.org/10.1002/cti2.1228. 